\title{
LANDFILL MINING: A CASE STUDY REGARDING SAMPLING, PROCESSING AND CHARACTERIZATION OF EXCAVATED WASTE FROM AN AUSTRIAN LANDFILL

\author{
Cristina García López ${ }^{1, \star}$, Bastian Küppers ${ }^{2}$, Adele Clausen ${ }^{1}$ and Thomas Pretz ${ }^{1}$
}

${ }^{1}$ Department of Processing and Recycling, RWTH Aachen University, Aachen, 52062, Germany

${ }^{2}$ Chair of Waste Processing Technology and Waste Management, Montanuniversitaet Leoben, Leoben, 8700, Austria

Article Info:

Received:

17 January 2018

Revised:

14 May 2018

Accepted:

24 June 2018

Available online:

30 June 2018

Keywords:

Landfilled waste

Mechanical biological treatment

Enhanced landfill mining

Landfill directive

Recycling

New mine

\section{ABSTRACT}

The following case study belongs to the New-Mine project and the objective of the project is to develop a new "Enhanced Landfill Mining" (ELFM) scenario for a combined resource-recovery and remediation strategy. This strategy could reduce future remediation costs and reclaim valuable land while simultaneously unlocking valuable resources. In the past, insufficiently reliable data about the composition of landfills, overestimation of the quality of excavated material and poor product marketing of the possible recyclables have resulted in a bad reputation for landfill-mining projects. The ongoing research in the NEW-MINE project shall show that there are possibilities to create valuable outputs from landfills with enhanced treatment processes, such as a better distribution of the different mechanical processes. To create mechanical routes to recover valuable materials from old landfills, it is important to characterize the material, creating a basis for the research. The objective of this case study, executed from November 2016 until June 2017 at the landfill site in Halbenrain (Austria), is to study the efficiency of different sorting technologies with old landfill material. The excavated material was transported and used as feedstock in a configured state-of-the-art mechanical-biological treatment (MBT) plant located next to the landfill. During the mechanical processing, metals and high-calorific fractions were sorted out from the input flow. As a result of the mechanical processing, approx. $3 \%$ of the ferrous metals were recovered, approx. $20 \%$ of potential RDF (pRDF) was separated and could have been energetically recovered, and approx. $74 \%$ belonged to the finer fraction ( $<40 \mathrm{~mm}$ ). Each sample from the sampling campaign was sieved to obtain the particle size distribution. Via manual sorting, the material was classified into plastics, wood, paper, textile, inerts, Fe metal, NF metals, glass/ceramic and residuals. In addition, the moisture (wt\%), the ash content (wt\%), the calorific value $(\mathrm{MJ} / \mathrm{kg})$ and the concentration of heavy metals (\%) of the finer fraction $(<40$ $\mathrm{mm}$ ) were analysed. The aim of this study is to assess the possibilities of different mechanical processes with landfill mining (LFM) material and to gain information about the characterization of five material flows derived from the mechanical treatment, together with the mass balance of the MBT. Although every landfill has its own characteristics, the results obtained from this case study can help to understand the general potential, contribute to develop methodologies for characterization of old landfill material and identify problematic fields that require further research.

\section{INTRODUCTION}

As the world population increases, the generation of municipal solid waste (MSW) is increasing, and landfills continue to be filled with recyclables that could be used otherwise as raw materials or for energy recovery. The situation is even more critical if we look back in time. Before the European Directive 1999/31/CE was implemented and defined different categories of waste, MSW could have been mixed and buried without treatment/sorting according to local legislation. Moreover, insufficient disposal charges for landfilling did not prevent the negative impacts of landfills, either.

In the 1970s, there was a period of rapidly increasing raw material prices and rising concern about finite natural resources. Several studies forecasted serious shortages by the end of the century. Recycling of household waste was considered a partial solution to the problem. There 
was also increasing awareness regarding the negative impact of simple dumping without appropriate barrier systems or pretreatment prior to landfilling. Since then, many technological advances have been developed to produce refused-derived fuels (RDF) and to separate recyclable materials from residual MSW (Ferranti et al. 1985). However, despite the efforts in the last 40 years to improve the situation, landfilling is still the most common method of organized waste disposal in Europe, according to Eurostat.

In 2014, Europe treated 2319 mill t of MSW by six treatment operations, defined in the Waste Framework Directive 75/442/EEC: $41 \%$ disposal on land, $36 \%$ recovery (other than energy recovery - except backfilling), $10 \%$ recovery (backfilling), 7\% land treatment/release into water, 5\% energy recovery, and 1\% incineration (Eurostat, 2014). Figure 1 shows four of six management systems for MSW in Europe by country.

Currently, Europe accumulates between 150.000 and 500.000 old landfill sites, of which approximately $10 \%$ meet the EU Landfill Directive requirements and are considered sanitary landfills. In most cases, non-sanitary landfills lack the required environmental protection technologies and will eventually demand costly remediations to avoid future problems (NEW-MINE, 2016). Due to the existence of those non-sanitary and sanitary landfills, possible valuable resources are being lost and concurrently the environment and human health damaged. Therefore, remediation strategies for existing landfills are fundamental in the direction to preserve resources, environment and human health. A further argument to recover the valuable resources is the crisis that concerns the economic situation and the energetic matrix, which is mainly based on fossil fuels and water energy, where prices for energy and secondary resources are increasing steadily.

The composition inside a landfill generally depends on different parameters, such as waste regulations and legislation, differences in the waste management systems, recycling systems, standard of living and the society and culture of the setting (Quaghebeur et al., 2013). Proper investigations of each site, including the operation history, waste type dumped, dimensions of the landfill, topography and physical-chemical analyses, are necessary to make a careful feasibility analysis about the material potential inside the landfill (Salerni, 1995). Apart from considering the material potential, a critical factor to take in consideration before starting an ELFM project is the quality of the materials to recover and the market price, which varies over time and region.

The present work belongs to the New-Mine project, supported by the European Commission since September 2016 , in collaboration with another landfill mining project of FCC at the landfill site of Halbenrain (Austria). The scope of the project is to transform a large fraction of old excavated LFM into higher-added-value products. The project is designed to combine a remediation strategy with the recovery of resources, as seen in Figure 2.

The purpose of this study is to provide foundational knowledge of the composition and characteristics of excavated material from a specific MSW and Industrial landfill, which is important for the sizing of mechanical sorting. Moreover, this paper aims to assess the possibilities of different mechanical processes with landfill mining (LFM) material and to gain information about the characterization of five material flows derived from the mechanical treatment, together with the mass balance of the MBT. The novelty of this research is the biological treatment (drying stage) prior to mechanical treatment, in addition to the use of a complete MBT plant, which differs from other studies in which mobile machinery is applied.

Although every landfill has its own characteristics, the results obtained from this case study can help to understand general potentials, contribute to develop methodologies for characterization of old landfill material and identify problematic fields that require further research.

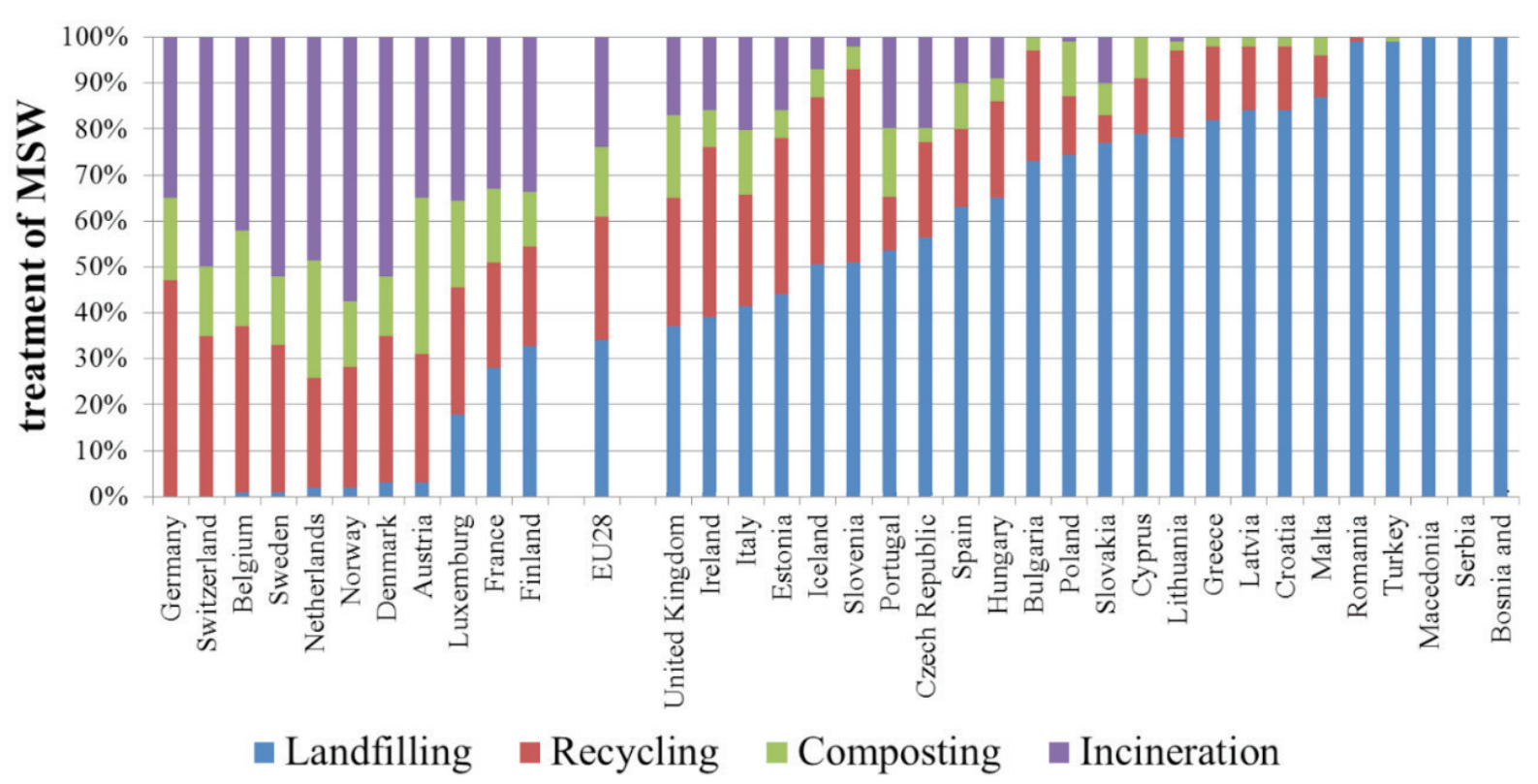

FIGURE 1: Relevance of the main MSW management systems in the EU-28 in 2012 (Source: Eurostat, 2014). 


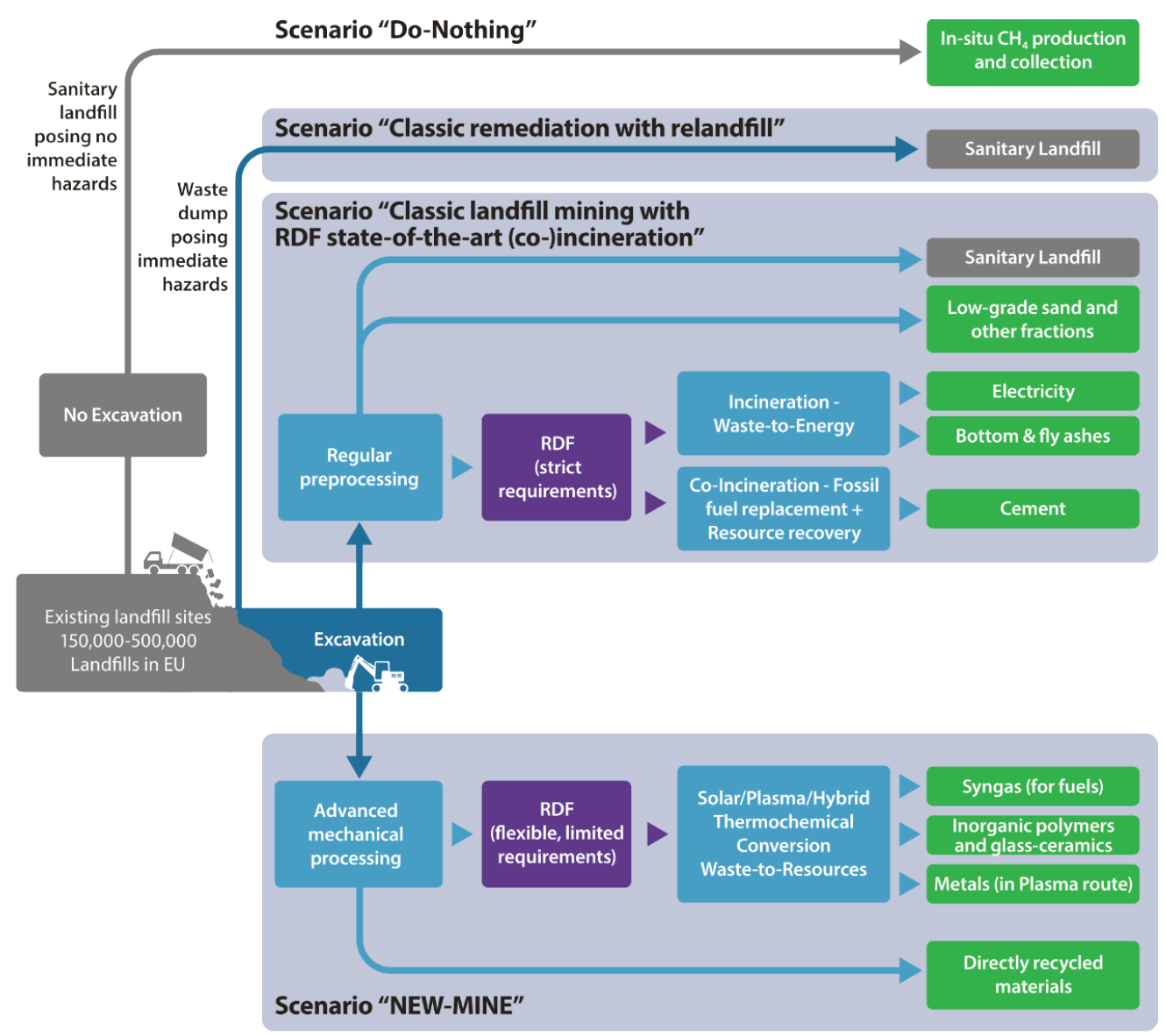

FIGURE 2: Comparison of different scenarios for the EU's landfills, Do-Nothing (only acceptable for well-monitored sanitary landfills), Classic Remediation (where the materials are excavated and re-landfilled), and Classic Landfill Mining coupled with (co)incineration, and the NEW-MINE, ELFM Scenario (Source: EURELCO www.new-mine.eu).

\section{MATERIAL AND METHODS}

\subsection{Site description}

The landfill site in Halbenrain belongs to FCC Halbenrain Waste Treatment Centre and is located $75 \mathrm{~km}$ southeast of Graz (Austria). The landfill was established in 1978 and received MSW and industrial waste. Currently, the examined area is in the post-closure phase, and it has an extension of $16 \mathrm{ha}$, with a total volume of 2.4 million $\mathrm{m}^{3}$ of waste. The site has developed over the years to include a waste disposal facility with leachate treatment, conversion of landfill gas into electricity, composting, sorting and mechanical-biological waste treatment.

\subsection{Excavation and processing at the site}

In June 2016, FCC initiated a landfill-mining project on site with the aim of recovering metals disposed between 1997 and 1999. Based on records about the landfill composition, eight areas of interest were estimated to contain a relatively high percentage of recyclable materials, being metals of great interest for ELFM. The material examined during the case study was extracted of the projected area

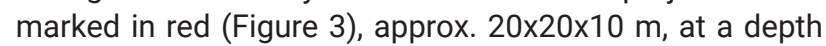
of $6 \mathrm{~m}$.

The mining activity included the following steps: 1) excavation (Figure 4), 2) transportation to a Mechanical and
Biological Treatment (MBT) plant, 3) biological treatment and 4) mechanical treatment with potential Refused Derived Fuels (RDF) separation and metal recovery.

During the case study, two batches (batch 1: $220 \mathrm{t}$, batch 2: $280 \mathrm{t}$ ) were excavated, treated and characterized.

Normally, MBT plants stand at the beginning of an efficient waste treatment process. By using a selective treatment process, unsorted waste can be separated into different fractions, which then can undergo further treatment (e.g., potential RDF) or be used for material recovery (metals). The design of these processes must be adapted to national regulations and market situations to be successful.

After the excavation, the LFM material was sent to an already-existing and configured MBT plant on site, which is used to treat fresh household waste. As a first step of the MBT process, the material was dried by aerobic activity (rotting boxes for 3-4 weeks). During this treatment, a loss of water of approx. $10 \mathrm{wt} \%$ and a possible organic matter reduction were achieved. Once the material was stabilized, it was sent to the full-scale mechanical process.

The semi-dry material was fed to a single shaft shredder that reduced the particle size of the material to 250 $\mathrm{mm}$. The shredder also transformed the input material to a uniform size and eliminated overlengths that could interfere with the successive process. Afterwards, an overbelt magnet separated the large pieces of ferrous metals. After 


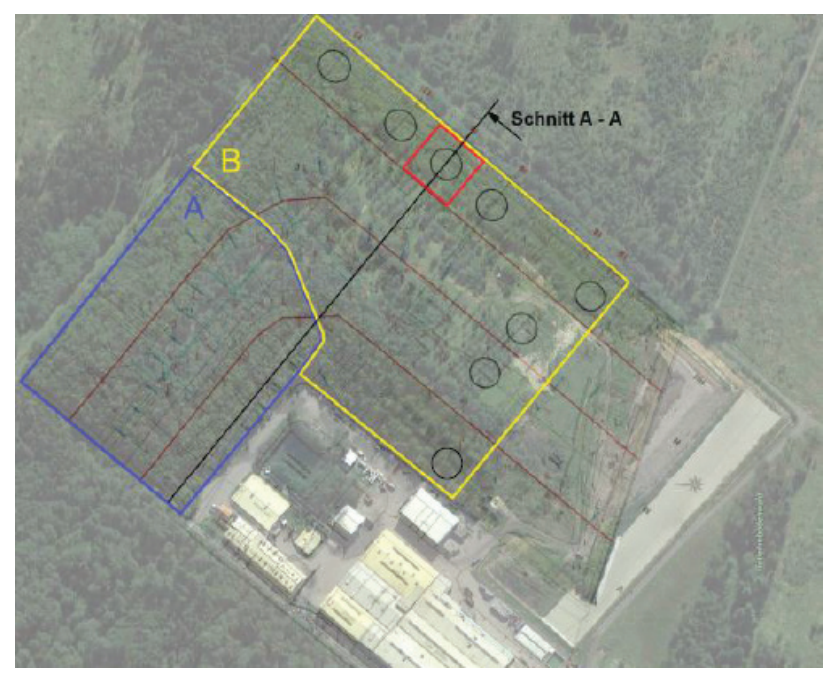

FIGURE 3: Overview of landfill site Halbenrain; A" filled 1979-1990; "B" filled after 1990; black circles mark especially interesting areas with higher amount of metals; projected area marked in red.

the magnet, the first sampling point (SP1) was established; see Figure 5

Due to the plant design, the input material (prior the magnetic separator) was not accessible as a sampling point, and the Fe-metal concentration (wt\%) sorted before the SP1 was calculated by measuring the weight of the pile after processing the batch of excavated waste. After passing the magnetic separator, the material was screened with circular vibratory screens with a mesh size of $60 \mathrm{~mm}$ (S1). The screen enabled the enrichment of metals and high calorific fractions - referred as potential RDF in the following - in the coarse and to concentrate the biogenic material in the underflow.

The material flows of the $250-60 \mathrm{~mm}$ and $<60 \mathrm{~mm}$ fractions were further processed and characterized:

1. The overflow, 250-60 mm, was sorted with an additional overbelt magnetic separator (MS2) and screened at a diameter of $200 \mathrm{~mm}$ (S2). The fines from the $200-\mathrm{mm}$ screen (fraction: $200-60 \mathrm{~mm}$ ) were treated with a zigzag windsifter to separate the light and heavy fractions of the flow. The coarse fraction, $250-200 \mathrm{~mm}$, was directly balled, together with the light fraction of the windsifter.

2. The underflow, $<60 \mathrm{~mm}$, was stored for further treatment. The results are not reported in the present publication.

\subsection{Sampling campaign}

The selection of a method for representative sampling is one of the most difficult decisions regarding waste flow analysis due to the material's heterogeneity. Normally, the material composition inside the landfill is variable, depending on the digging point chosen for the excavation. The sampling campaign was designed in order to obtain reliable information about different techniques of waste segregation (Figure 6).

In this study, the material was organized by batches, and during the processing of the whole batch, several sam-

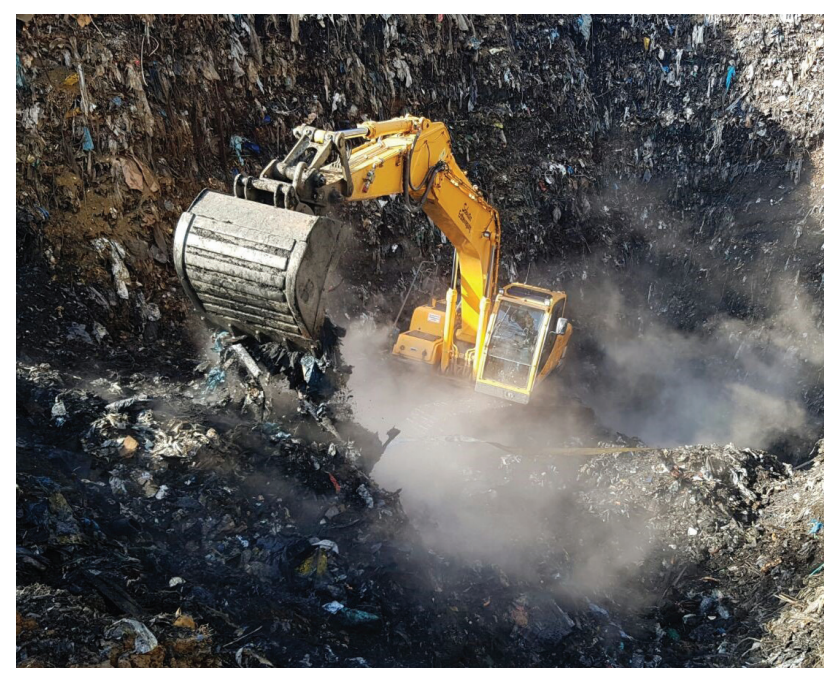

FIGURE 4: Excavation of LFM material from late 1990s at the landfill site in Halbenrain (Austria).

ples were taken at different times. The sampling points, labelled SPx in Figure 5, were directly conveyor belt discharges. The number ( $n$ ) of the single samples in each SPx was based on the German directive LAGA PN 98 - procedures for physical, chemical and biological testing in connection with the recovery/disposal of waste. LAGA PN 98 defines that the number of samples depends on the total quantity (m3) of the material flow (see Appendix A: Tables). The mass of the sample depends on the maximum diameter, Dmax, of the particle size (Formula 1) according to LAGA PN 78.

Single sample in $\mathrm{kg}=\mathrm{D}_{\max }[\mathrm{mm}] \times 0,06 \mathrm{~kg}$

During the sampling campaign, two batches of $~ 230$ $\mathrm{t} /$ batch of semi-dried landfill material were characterized.

\subsection{Mass balance}

The mass balance of the MBT plant in Halbenrain was calculated based on the batches that fed the MBT plant. The weight of both input and outputs were measured.

\subsection{Characterization of LFM material}

The outcome of the characterization helps to study the potential of landfills for raw materials. In addition, it provides data about the effect of MBT technology with old LFM waste. It has to be noted that the facility used during this case study was not designed for treating old landfilled material. Therefore, the choice of the technology in the process was not perfectly optimized for the treatment, and the results of the sorting should be interpreted with care.

The quantity and quality of the LFM material after each mechanical process were determined based on the particle size distributions in each material flow, classifying each sample by hand (Table 1 ) and analysing physical and chemical characteristics of the fine fractions $(<40 \mathrm{~mm})$.

\subsubsection{Bulk density}

The bulk density of each material flow at SP1, SP2, SP3, 


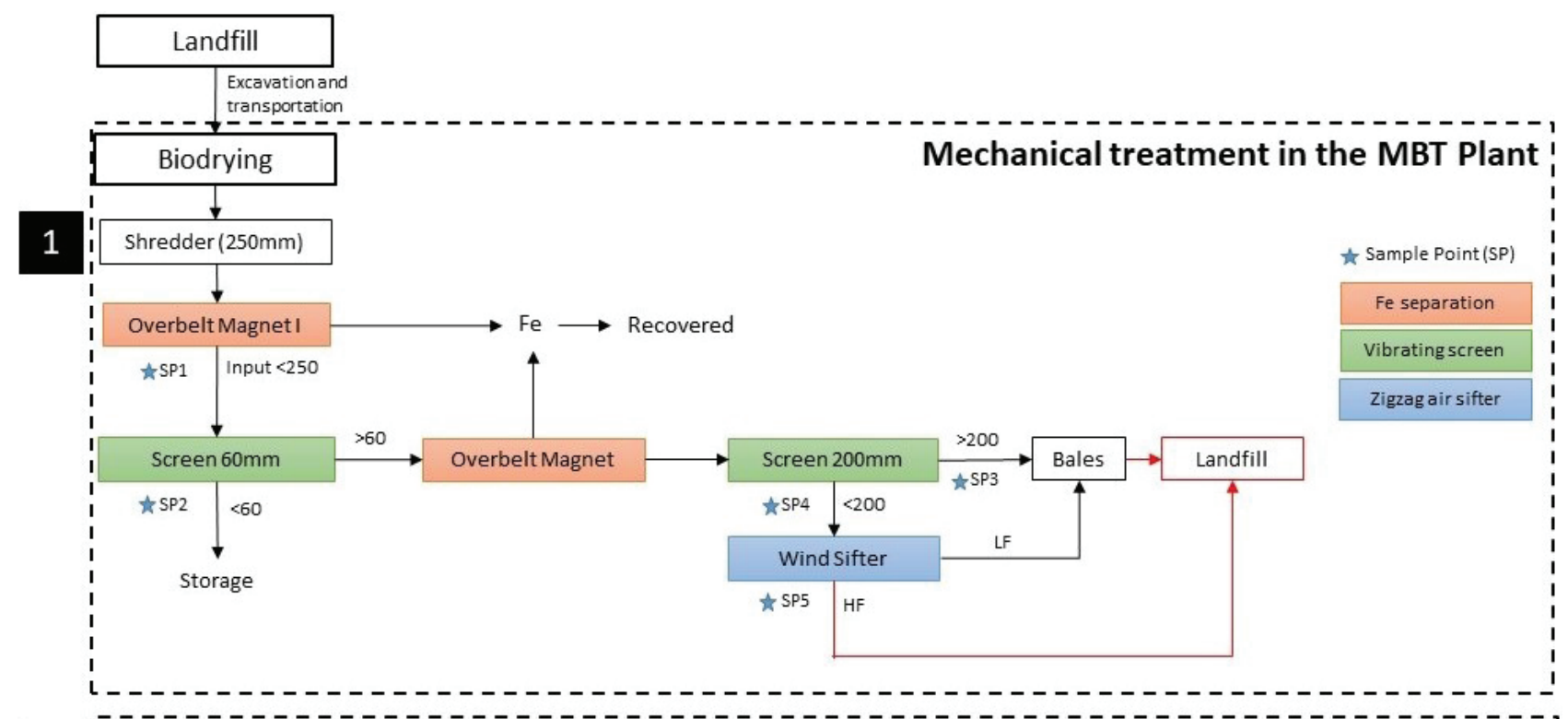

2

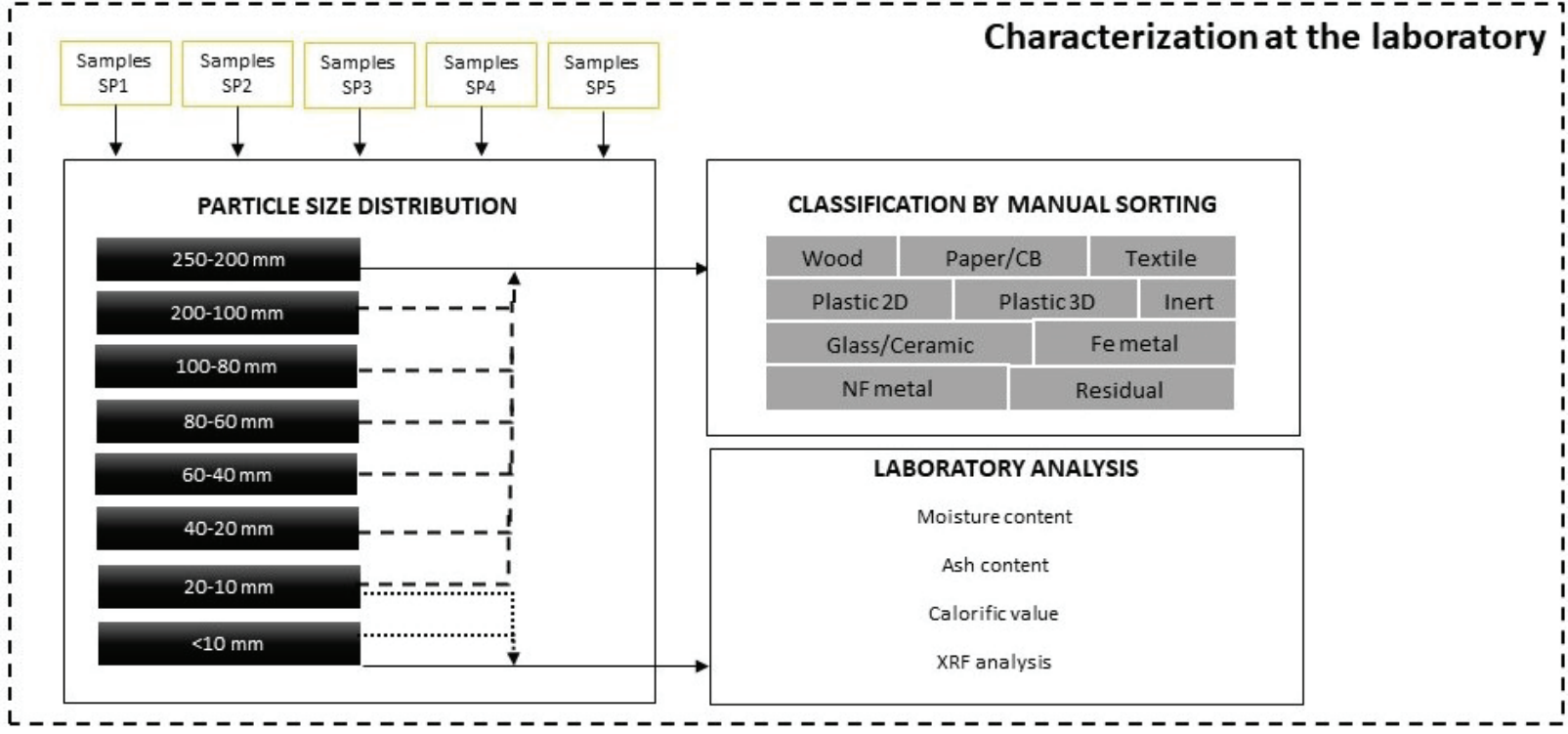

FIGURE 5: Methodology for the characterization of the LFM material in Halbenrain (Part 1: flowchart of the MBT process at the site with sampling points (SPx); Part 2: characterization of the smaller fractions $<40 \mathrm{~mm}$ in the laboratory).
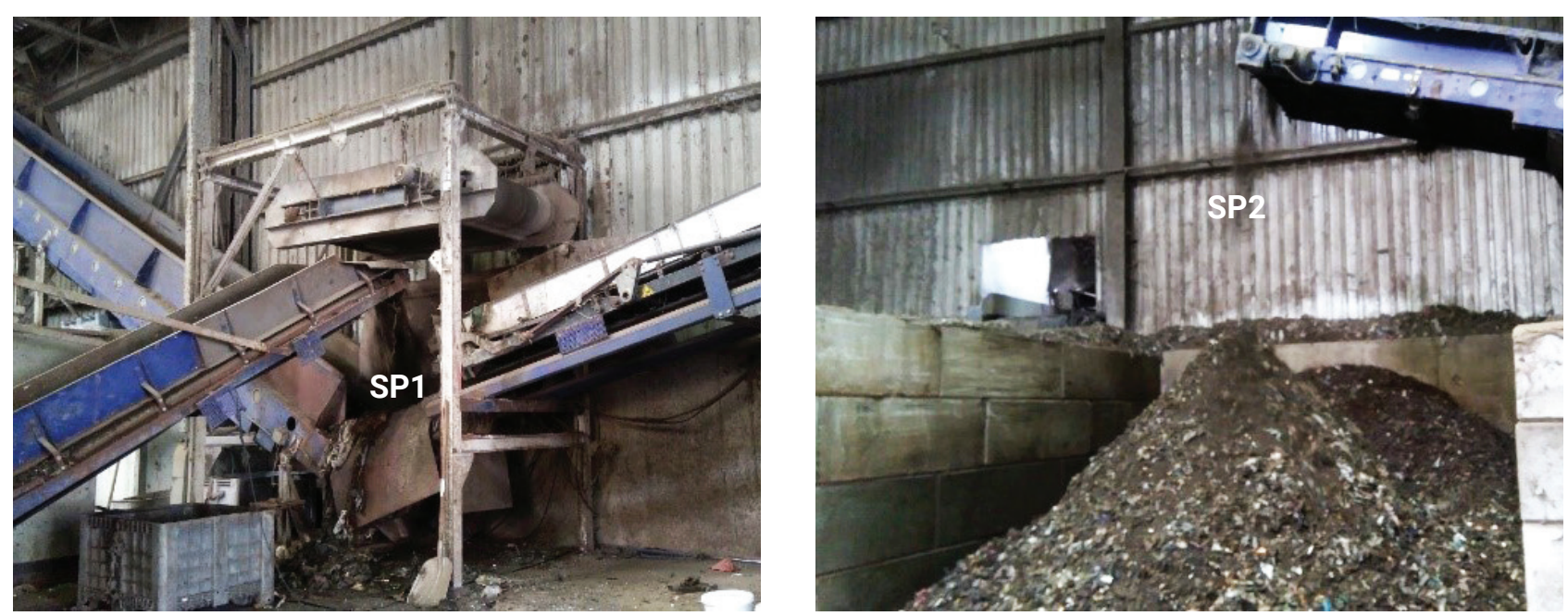

FIGURE 6: Input material after a shredder and an overbelt magnet, SP1 (left) and fines from the first screen 60 mm, SP2 (right). 
SP4 and SP5 was computed by taking the mean of several filling recipients of $90 \mathrm{~L}$ directly from the flow and measuring its weight.

\subsubsection{Particle size distribution analysis}

Each composite sample from each sampling point was individually sieved for 90 seconds using drum sieves with the following mesh sizes: 200, 100, 80, 60, 40, 20, and $10 \mathrm{~mm}$. The particle size distribution helps to determine in which fractions of the flow desired materials are concentrated.

\subsubsection{Manual sorting}

The outcome of the drum sieve were eight fractions: $>200 \mathrm{~mm}, 200-100 \mathrm{~mm}, 100-80 \mathrm{~mm}, 80-60 \mathrm{~mm}, 60-40 \mathrm{~mm}$, 40-20 mm, 20-10 mm and < $10 \mathrm{~mm}$. Subsequently, all fractions $>10 \mathrm{~mm}$ were sorted manually and classified into 10 categories (Table 1).

\subsection{Characterization at the laboratory: physical-chem- ical analysis}

The fine fractions $<40 \mathrm{~mm}(40-20 \mathrm{~mm} ; 20-10 \mathrm{~mm} ;<10$ $\mathrm{mm}$ ) were reduced in mass based on the German standard given in the previous chapter 2.3 and delivered to the RWTH Aachen University. Further analysis was performed with the objective to estimate the waste-to-energy characteristics (moisture content, ash content, calorific value and heavy metal concentration; Jani et al. 2016). To be able to analyse the last three parameters, the particle of the samples had to be mechanically reduced to $<2 \mathrm{~mm}$, and each sample $(<40 \mathrm{~mm})$ was separated into 3 subcategories: light fraction (LF), heavy fraction or rest (HF) and metals.

\subsubsection{Moisture content}

The moisture content of waste is closely related to the amount of organic matter, and it differs with the habits of the population. In the EU and the USA, it ranges from 20$30 \%$, whereas values in China are from $30-60 \%$ due to the higher content of kitchen garbage (Jani et al., 2016).

Looking at existing landfills, different factors affect the moisture content, e.g., the type, composition and properties of the waste, climatic conditions, landfill operating system and soil cover layer (Hull et al., 2005). The moisture con-

TABLE 1: Classification by categories.

\begin{tabular}{|c|c|}
\hline Category & Material \\
\hline Wood & All types of wood \\
\hline Paper & Paper/cardboard/composite carton \\
\hline Textile & All types of textile \\
\hline Plastic 2D & $\begin{array}{l}\text { Aluminum package/bags (transparent/white/col- } \\
\text { ored) }\end{array}$ \\
\hline Plastic 3D & PP/PET/PET Oil/PEAD/PEBD/PVC/PS/Others \\
\hline Fe metals & Iron \\
\hline NF metals & Copper/Aluminum can/steel \\
\hline Inerts & Mineral fraction (stones) \\
\hline Glass & Colorless glass/green glass/brown glass/others \\
\hline Residual & $\begin{array}{l}\text { Sanitary material, rubber, foam, silicone, melted plas- } \\
\text { tics, sandpaper, electronic plates, hazards, undefined }\end{array}$ \\
\hline
\end{tabular}

tent is important when considering the recycling of waste to produce energy through biological and/or thermal treatment (Brunner and Rechberger, 2015), in addition to for sorting the material during the mechanical pretreatment.

The standard DIN EN 14346:2007 "Characterization of waste - Calculation of dry matter by determination of dry residue or water content" suggests to dry the samples at $105^{\circ} \mathrm{C}$. However, volatile fractions would also evaporate at this temperature, making certain plastic particles melt, thus resulting in a less precise analysis. Therefore, the moisture content was determined by drying the samples of each material flow in a ventilated oven at $75^{\circ} \mathrm{C}$ until reaching a constant temperature.

\subsubsection{Particle size reduction (pretreatment)}

After the drying process, a reduction of the particle size of three fractions ( $40-20 \mathrm{~mm}, 20-10 \mathrm{~mm}$ and $<10 \mathrm{~mm}$ ) was necessary to analyse the calorific value and organic content and to determine the heavy metals. Each sample was classified with an air sifter into a light fraction (LF) and a heavy fraction (HF). The metals contained in the sample were sorted previously using a magnet to avoid damage caused by further processing machines. In general, the LF had larger particle sizes than the remaining inerts in the flow. By sieving, using a mesh size of $2 \mathrm{~mm}$, the LF could be freed of the majority of the inerts. The HF was crushed with a hammer mill and afterwards grinded in a disk mill. In the case of LF with a particle size $>2 \mathrm{~mm}$, a cryogenic comminution method using liquid nitrogen was used to reduce in size flexible materials such as $2 \mathrm{D}$ plastics. The result of comminution was a powder or flakes with sizes $<2 \mathrm{~mm}$ for the LF and $<1 \mathrm{~mm}$ for the HF.

This reduction (pretreatment) is needed to provide relatively homogenic material fractions in comparison to the initial material for further tests (ash content, calorific value and XRF analysis). The mass of each fraction (LF, HF/rest and metals) was measured to consider the share of each, in wt\%.

\subsubsection{Ash content}

The ash content/organic content was calculated using $1 \mathrm{~g}$ of sample in each fraction, $40-20 \mathrm{~mm}, 20-10 \mathrm{~mm}$ and $<10 \mathrm{~mm}$ (from SP1), and analysed by using a muffle furnace according to DIN EN 14775.

The volatile compounds calculated as the difference between the initial weight in the test and the weight of the remaining solids after the incineration is an indicator of the organic matter content.

\subsubsection{Net calorific value}

The calorific value was determined for the same samples as for the organic content. In this case, a bomb calorimeter was used according to the standard DIN 51900. The test consisted of complete combustion with oxygen of approx. $0.5 \mathrm{~g}$ of a dried sample in a bomb with a pressure of 40 bars. The heat transmitted to the surrounding water was measured and the net calorific value calculated accordingly.

\subsubsection{XRF analysis}

The content of heavy metals was determined with a 
Niton $^{\text {TM }}$ XL3t X-ray fluorescence (XRF) spectrometer. For the analysis, the samples of each fraction $(<10 \mathrm{~mm}, 10-20$ $\mathrm{mm}$ and $20-40 \mathrm{~mm}$ ) of the sampling points (SP1-SP5) were analysed eight times. Afterwards, the mean values for all samples and the standard deviation were computed.

\section{RESULTS AND DISCUSSION}

\subsection{Mass balance of the MBT plant with LFM material}

In total, $2786 \mathrm{t}$ of excavated material were treated mechanically, and $3 \%$ of Fe metal was recovered. The rest of the output flows with possible recoverable materials were landfilled again. Figure 7 depicts the mass balance of the MBT plant.

\subsection{Characterization of the material flows}

\subsubsection{Bulk density}

The bulk density depends on both the density and arrangement (compaction) of the particles in the flow. For instance, the bulk density in the input material flow (SP1), with a particle size $250-0 \mathrm{~mm}$, was $0.25 \mathrm{t} / \mathrm{m}^{3}$ (see Table 2), whereas higher-bulk-density material was found in the fine fraction $(<60 \mathrm{~mm})$ of the $60-\mathrm{mm}$ screen, with $0.62 \mathrm{t} / \mathrm{m}^{3}$. The coarses "250-200 mm" had a lower bulk density $(0.05 \mathrm{t} /$ $\left.\mathrm{m}^{3}\right)$ compared to the fines "200-60 mm" $\left(0.18 \mathrm{t} / \mathrm{m}^{3}\right)$. This result can be explained with the enrichment of light material types such as foils in the coarses and an increased amount of e.g., inerts and wood in the fines. These shifts in the composition can be explained as a result of the effects of the screening has on the material flow.
TABLE 2: Mean values of the bulk density at each sampling point (SP1-SP5) of the MBT plant.

\begin{tabular}{c|c} 
Sampling point & Bulk density $\mathbf{~} / \mathbf{m}^{\mathbf{3}}$ \\
\hline SP1 & 0,25 \\
\hline SP2 & 0,62 \\
\hline SP3 & 0,05 \\
\hline SP4 & 0,18 \\
\hline SP5 & 0,27 \\
\hline
\end{tabular}

\subsubsection{Composition of the material flows}

Input flow of the mechanical treatment $(<250 \mathrm{~mm})$ (SP1). The composition of the input flow is decisive for the rest of the flows in the plant, since this is the raw material that shall be classified, sorted by density, magnetism, induction, etc. Figure 8 shows the average composition (wt\%), where the largest proportion is the fine fraction $(<10$ $\mathrm{mm})$, with approx. $50 \%$ of the total mass. The fines $(<10$ $\mathrm{mm}$ ) are mainly soil, glass shards and mineralized organic matter. In chapter 2.3., "Physical-chemical analysis", one finds a detailed characterization of this fraction in the input flow (SP1). The content of ferrous metals (Fe), as presented here, must be considered with care, since it is only representative for the material flow after the first magnetic separation unit (overbelt magnet).

It must be considered that the weight of most defilements (fine particles) remains on the manual sorted fractions (wood, paper, plastics, etc.). These defilements not only have the effect of changing the mass balance but can

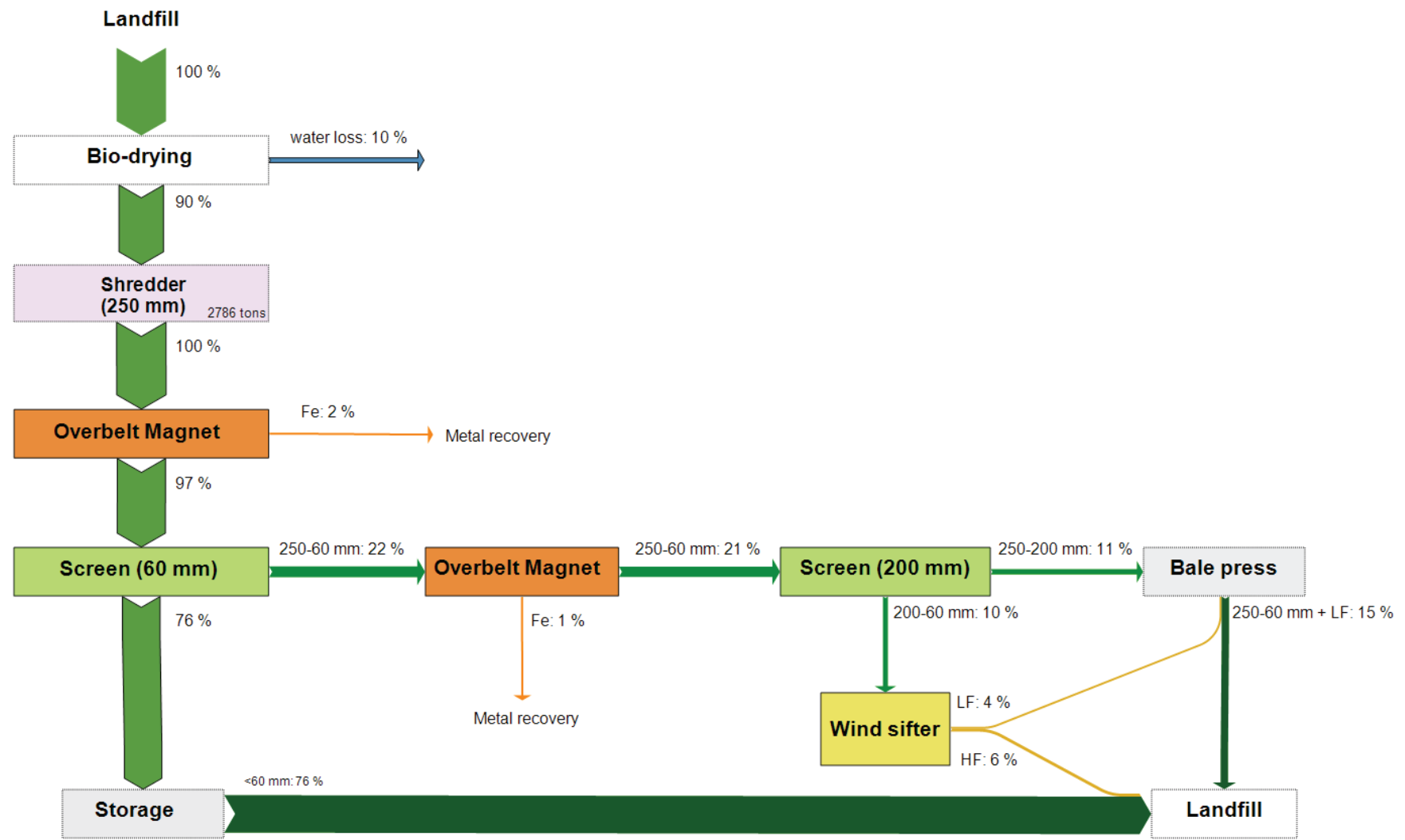

FIGURE 7: Mass balance of the MBT in Halbenrain (Austria). 

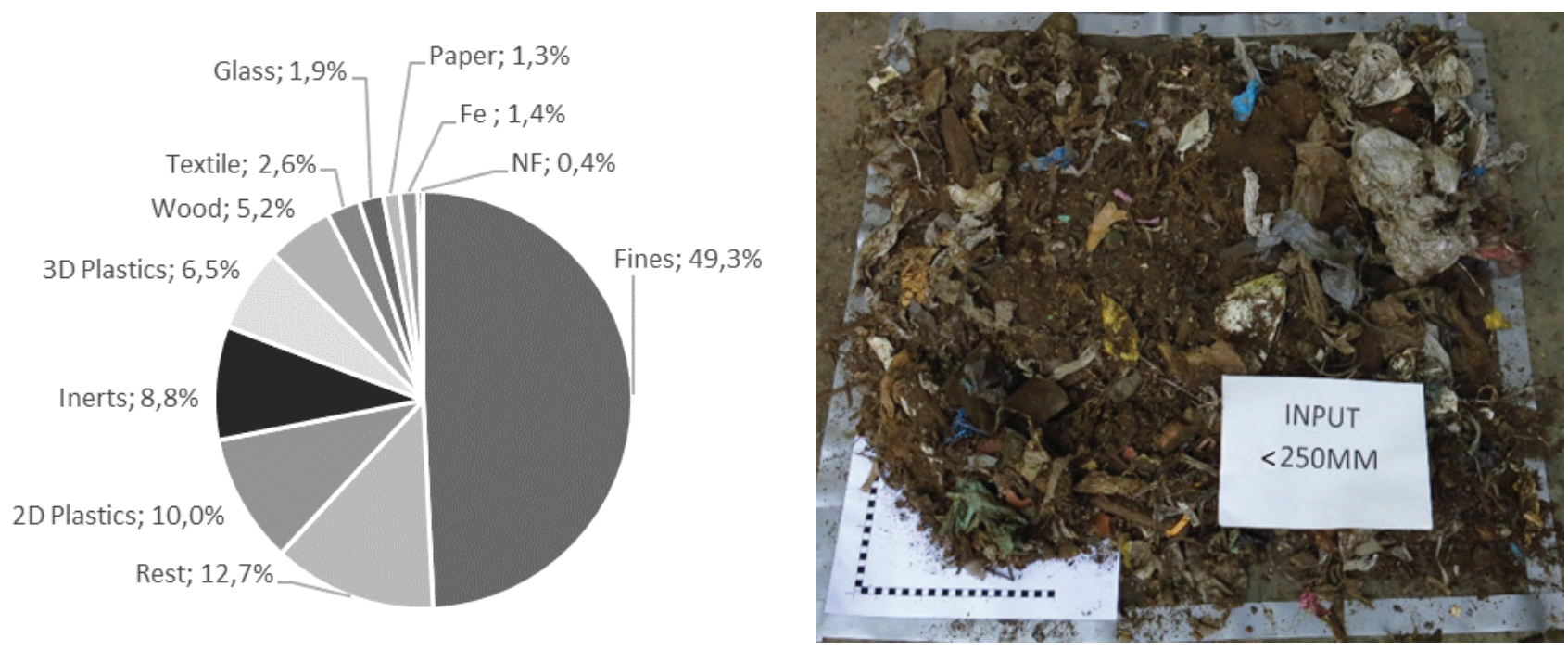

FIGURE 8: Average composition (wt\%) of the material supplied in the MBT plant during the sampling campaign after a shredder and a magnet separator, SP1.

also reduce the heating value. The influence of the defilements attached to coarse particles is larger for flat particles (e.g., 2D plastic) since the surface is bigger in comparison to the total weight of a particle than it is for round or cubic objects.

The results from the input composition cannot be used for comparison with earlier studies in a reliable manner since the proceeding in each investigation varies. In this manner, the results are not properly comparable due to differences in properties and pre-processing, e.g., moisture content, analytical approach, mechanical and/or biological treatment. Once a common methodology is used, a proper comparison can be possible. However, the amount of fines $(<10 \mathrm{~mm}$ ) found in Halbenrain, $49 \%$, is comparable to those found in Kuopio, Finland, with $50-54 \%$ (Kaartinen et al., 2013); Lower Austria, Austria, with 47\% (Wolfsberger et al., 2015); and Remo, Belgium, with $44 \pm 12 \%$ (Quaghebeur et al., 2013). Regarding the amount of plastics (2D and 3D plastics), Halbenrain accounts for $16.5 \%$, whereas the amount in Kuopio, Kudjape, Lower Austria and Remo are $23 \%, 22.4 \%$ (Bhatnagar et al., 2017), $18 \%$, and $17 \pm 10 \%$, respectively.

The variability of the results from 12 samples taken in the same sampling point (SP1) can be observed in Figure 9.

The absolute fluctuation in fines $(<10 \mathrm{~mm})$ is greater than in the remaining smaller categories, e.g., Fe, NFe, and glass. In fines $(<10 \mathrm{~mm})$, there is a $13 \%$ absolute variation, whereas the ferrous content fluctuates $4 \%$, but its relative fluctuation is greater than the one of the fines $(<10 \mathrm{~mm})$, resulting in a bigger impact on the amount of product that can be generated from it. In this manner, for example, the potential revenues would rather be affected by ferrous fluctuations since this material type is initially more marketable than the fines $(<10 \mathrm{~mm})$.

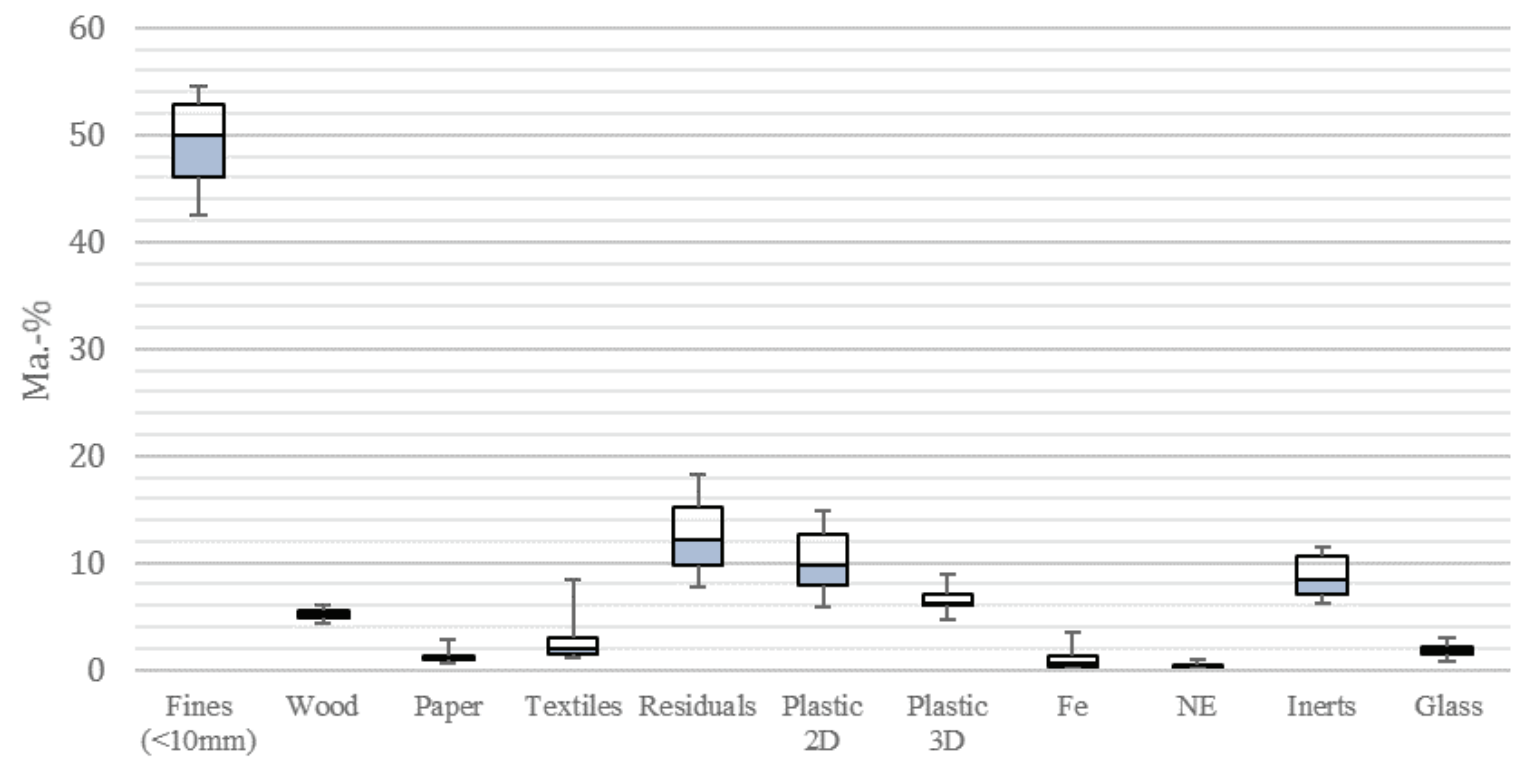

FIGURE 9: Range of the share of different material groups in the input flow of both batches $(n=12)$. 
Figure 10 shows the composition of the input material and other sampling points after each mechanical step, \%wt semidry basis. See Appendix A for more information.

Output flow of the screen $60 \mathrm{~mm}$ - fine fraction $(<60$ $\mathrm{mm}$ ) (SP2). The fines from the $60-\mathrm{mm}$ screen mainly consist of $<10 \mathrm{~mm}$ fines, which account for approx. $71 \%$; see Figure 10. Impurities in the flow are also found, including plastic particles (6\%), glass (3\%) and metals (1\%). The content of glass in this material flow is greater than in the rest of the examined flows. The screening efficiency turned out to be lower than expected, resulting in an increased amount of fines in the coarses flow. This reduced efficiency can be ascribed to agglomeration of fines.

Output flow of the 200-mm screen - coarse fraction (250-200 mm) (SP3). The coarses of the 60-mm screen (250-60 $\mathrm{mm}$ ) were sorted by a second magnet separator and sieved with a $200-\mathrm{mm}$ screen. The amounts of fines in the flow are reduced, but there is still a remaining portion of $7.1 \%$, which indicates that screening efficiency and the quality of the material. In the next chapter, regarding the particle size distribution, the efficiency of the screen can be assessed. This flow is characterized by its light fraction of 2D plastics (28.9\%), followed by 3D plastics $(21.2 \%)$, residuals $(16.6 \%)$ and textiles $(13.7 \%)$. This is an example that demonstrates the necessity of cleaning the material flow of impurities (mineral fraction) and concentrating the potential RDF (plastics, wood, textiles, and paper) via screening.

Output flow of the 200-mm screen - fine fraction (200 $-60 \mathrm{~mm}$ ) (SP4). The fine fraction from the $200-\mathrm{mm}$ screen (200-60 mm) consists of a large share of inerts (20.2\%), which could have been part of the covering layer of the landfill. MSW rarely consists of that many medium-sized stones. Apart from inerts, 3D and 2D plastics account for the biggest share in the composition of the flow. Once again, a significant amount of fines ( $<10 \mathrm{~mm}), 8.9 \%$, was found. The screening efficiency could have been improved by using a bigger screen or a mesh size with a bigger opening size surface. The order of the 200 - and $60-\mathrm{mm}$ screens should have been switched, performing coarse screening first and afterwards using the $60-\mathrm{mm}$ screen. In this case, the mechanical process was already configured prior the landfill mining project.

Output flow of the windsifter I - heavy fraction (HF 200 $-60 \mathrm{~mm}$ ) (SP5). The input material of the windsifter had a particle size of $60-200 \mathrm{~mm}$. The major categories inside the heavy fraction flow are inerts (34.5\%), wood (19.6\%) and 3D-plastics (24.1\%). The LF flow had an enrichment of 2D plastics, paper, textile and fines, which were almost removed from the heavy fraction flow. In addition, a big share of metals was found in the HF flow in comparison to the rest of the material flows. Hypothetically, a magnetic and an eddy current separator, after the windsifter in the heavy fraction, could have recovered $3.2 \%$ of Fe metals and $1.7 \%$ of NF metals. Instead, these valuable metals were returned to the landfill.

\subsubsection{Particle size distribution of the material flows}

The results for the particle size distribution demonstrate the efficiency of the screens and other sorting aggregates according to the grain sizes: $<10 \mathrm{~mm}, 10-20 \mathrm{~mm}$, 20-40 mm, 40-60 mm, 60-80 mm, 80-100 mm, 100-200 mm and $200-250 \mathrm{~mm}$. Figure 11 provides an overview of percentage of the total mass by particle and the cumulative screening throughput in the input material flow $<250 \mathrm{~mm}$ (SP1).

Input material flow (SP1): The composition of the coarses ( $>40 \mathrm{~mm}$ ), Table 3 , consists of mainly potential RDF (pRDF) materials, which are 2D and 3D plastics, textiles and wood with supposedly high calorific value, whereas the opposite is true for inerts, metals and glass. In addition, the category "residuals" contains a high concentration of combustibles, such as nappies, which could also be val-

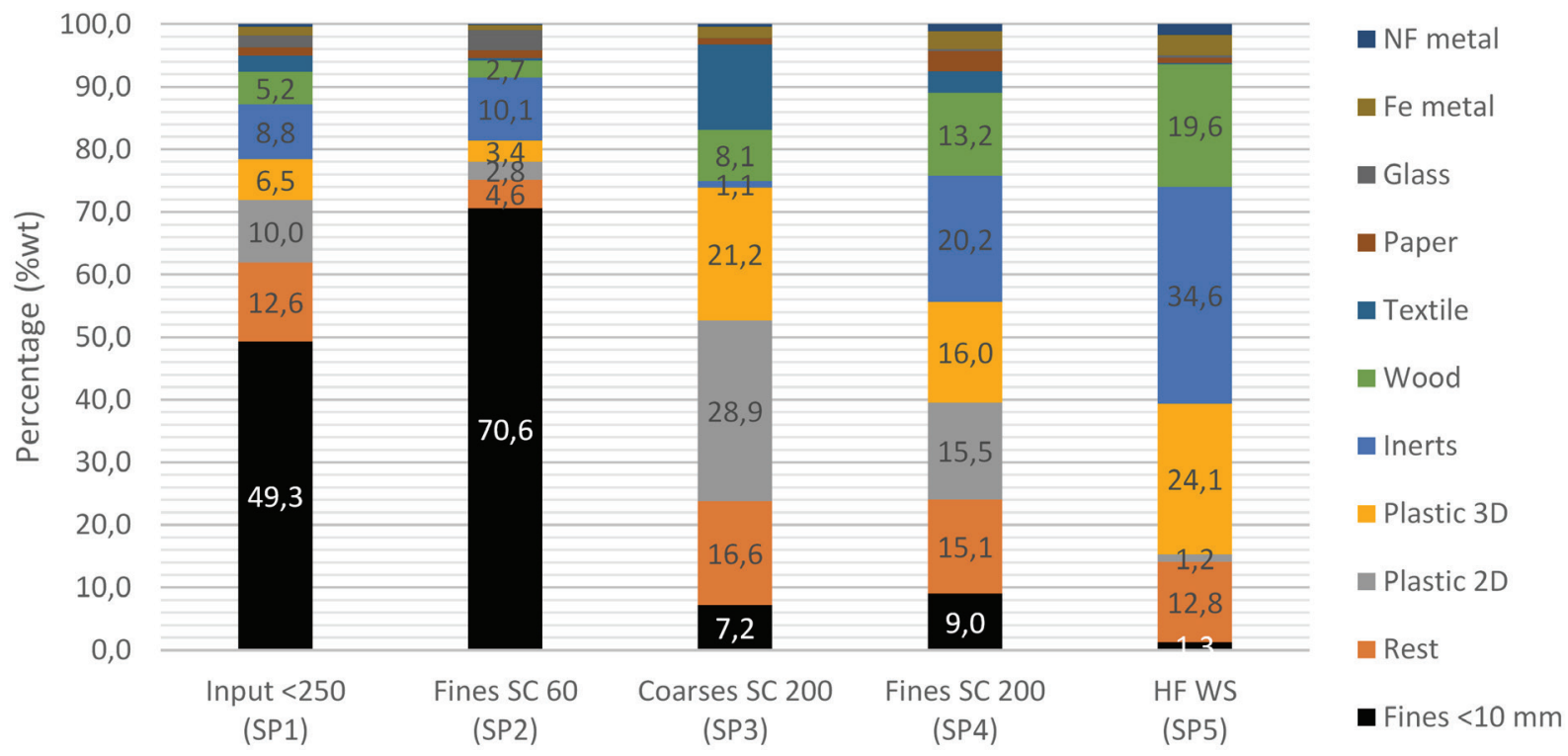

FIGURE 10: Composition of the input material (SP1) and output flows after each mechanical process (SP2, SP3, SP4, SP5). 


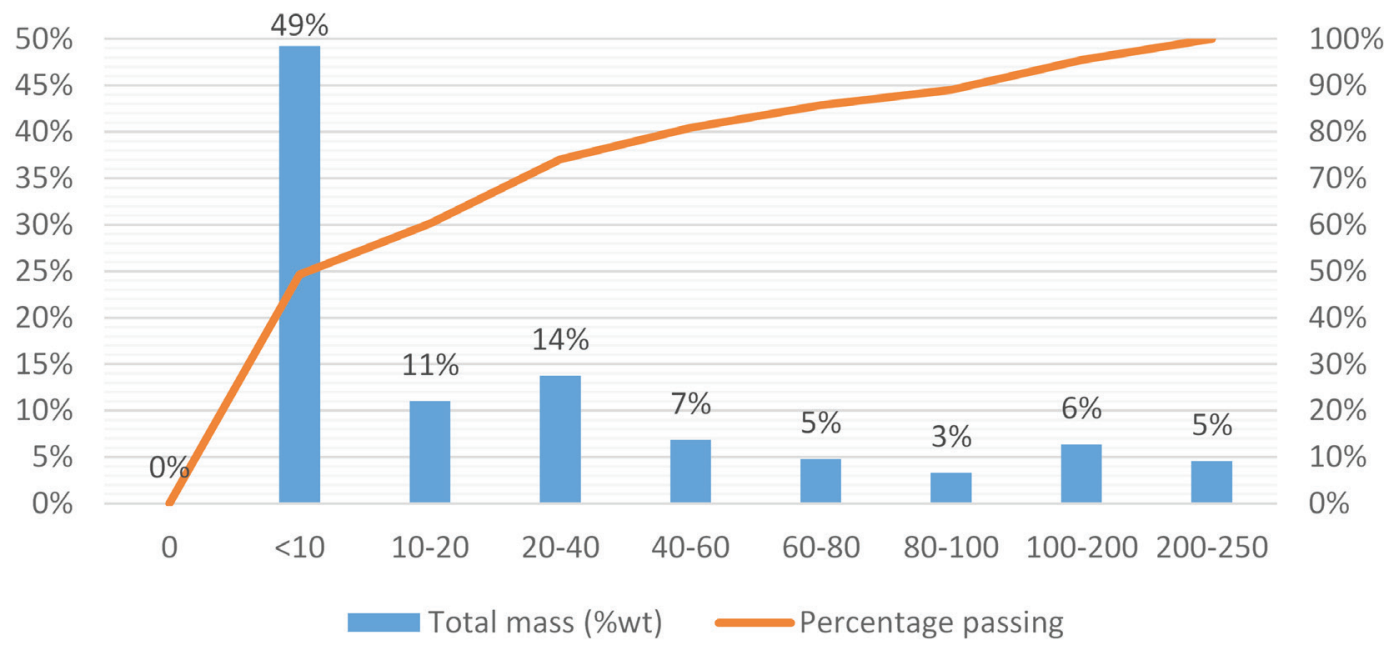

FIGURE 11: Particle size distribution of the input flow (SP1).

orized energetically. The amounts of NF and Fe in the input flow remain relatively low.

The fine fraction $(<40 \mathrm{~mm})$ in SP1 represents approx. $74 \mathrm{wt} \%$ of the entire input mass flow, being $60 \%$ the share of $<20 \mathrm{~mm}$ and $49 \%$ of $<10 \mathrm{~mm}$. Similar amounts of fines have been found in previous characterizations of fine fraction mined. For example, the fine fractions $(<20 \mathrm{~mm})$ of two MSW landfills in Finland, Lohja and Kuopio, were on average $45 \% \pm 7 \%$ and $58 \% \pm 11 \%$, respectively (Mönkäre, T. J. et al. 2015), similar to U.S. landfill reclamation projects: at least $50 \%$ and $46 \%$ of the excavated material were $<25$ $\mathrm{mm}$ in a landfill in New Jersey and one in Delaware, respectively (Hull et al. 2005; Miller et al. 1991), and in a landfill in Pennsylvania and one in Florida, approx. 41\% and 60\% were $<20$ mm (Forster 1994; Von Stein et al. 1993).

Table 4 presents the pRDF materials fractions in different particle size ranges. In the case of the coarse fraction, $>80 \mathrm{~mm}$, there is a bigger share of plastics and textiles.
Wood and paper have a greater share in the size range of 20-100 $\mathrm{mm}$ than in the rest of fractions.

Initially, the composition of the LFM material is not very positive in terms of finding large quantities of recyclables, Table 5, but via biological and mechanical treatment, this complex material can be partly cleaned from impurities (particles $<40 \mathrm{~mm}$ ), and possible desirable materials, e.g., pRDF, metals and soil can be sorted out from the flow for further treatment processes, e.g., thermal valorization, fines treatment, and metal recycling.

As seen from the results of the mechanical processing, the coarse flow of the $200-\mathrm{mm}$ screen $(250-200 \mathrm{~mm})$ is an example of enrichment of pRDF. The amount of pRDF in the particle size fraction $100-200 \mathrm{~mm}$ of the input material is $7.3 \mathrm{wt} \%$, whereas in the coarses of the $200-\mathrm{mm}$ screens, in the same particle size class, is $28.5 \mathrm{wt} \%$. The treatment of these would reduce the landfill volume that is occupied. Another point of the sieving is to classify the material by

TABLE 3: Comparison of the composition of the particle size classes in the input material flow (SP1), wt\%.

\begin{tabular}{|c|c|c|c|c|c|c|c|c|}
\hline Particle size (mm) & $<10$ & $10-20$ & $20-40$ & $40-60$ & $60-80$ & $80-100$ & $100-200$ & $200-250$ \\
\hline RDF & 0 & 28 & 43 & 55 & 60 & 64 & 63 & 88 \\
\hline $\mathrm{Fe}$ & 0 & 2 & 4 & 4 & 1 & 3 & 1 & 2 \\
\hline NF & 0 & 0 & 1 & 2 & 1 & 2 & 0 & 0 \\
\hline Inerts & 0 & 22 & 23 & 23 & 18 & 8 & 8 & 0 \\
\hline Glass & 0 & 9 & 6 & 1 & 1 & 0 & 0 & 0 \\
\hline Residual & 0 & 38 & 24 & 16 & 18 & 22 & 28 & 10 \\
\hline Fines & 100 & 0 & 0 & 0 & 0 & 0 & 0 & 0 \\
\hline
\end{tabular}

TABLE 4: High calorific materials by particle sizes in the input material flow (SP1), wt\%.

\begin{tabular}{|c|c|c|c|c|c|c|c|c|}
\hline Particle size (mm) & $<10$ & $10-20$ & $20-40$ & $40-60$ & $60-80$ & $80-100$ & $100-200$ & $200-250$ \\
\hline Wood & 0 & 9 & 13 & 13 & 15 & 10 & 7 & 0 \\
\hline Paper & 0 & 2 & 4 & 4 & 3 & 3 & 1 & 0 \\
\hline Textile & 0 & 0 & 1 & 2 & 4 & 7 & 7 & 26 \\
\hline Plastic 2D & 0 & 10 & 13 & 19 & 21 & 25 & 32 & 43 \\
\hline Plastic 3D & 0 & 7 & 12 & 17 & 17 & 20 & 16 & 19 \\
\hline
\end{tabular}


TABLE 5: Total mass of the input material flow and percentage by categories in the input material after a magnetic separator, wt\%.

\begin{tabular}{|c|c|c|}
\hline Categories & $\begin{array}{c}\text { Coarse fraction } \\
250-40 \mathrm{~mm}\end{array}$ & $\begin{array}{c}\text { Fine fraction } \\
<40 \mathrm{~mm}\end{array}$ \\
\hline Wood & 2 & 3 \\
\hline Paper & 1 & 1 \\
\hline Textile & 2 & 0 \\
\hline 2D Plastics & 7 & 3 \\
\hline 3D Plastics & 5 & 2 \\
\hline Fe metals* & $1 *$ & $1 *$ \\
\hline NFe metals & 0 & 0 \\
\hline Inerts & 3 & 6 \\
\hline Glass & 0 & 2 \\
\hline Rest & 5 & 8 \\
\hline Fines $(<10 \mathrm{~mm})$ & 0 & 49 \\
\hline Total & 26 & 74 \\
\hline
\end{tabular}

* Fe metals sum a total of $3 \%$ in the initial material feedstock. The amount of Fe-metals in this table is reduced due to the influence of an over-belt magnetic separator prior the sampling point SP1.

size and achieve a higher efficiency in the following mechanical treatment. For example, according to Pretz et al. 2010, for an effective windsifter treatment, the ratio between the maximum and minimum particle sizes should not exceed 3:1. Even though the grain size range of 60-200 $\mathrm{mm}$ used in the MBT did not match the recommendations, still, the air sifting process was satisfactory. The windsifter helped to reduce the impurities contained in the fraction with a size from $200-60 \mathrm{~mm}$, from a share of $8.9 \mathrm{wt} \%$ of fines $(<10 \mathrm{~mm})$ to $1.3 \mathrm{wt} \%$. Furthermore, the windsifter concentrates the heavy fraction, which commonly consists of 3D plastics, inerts and metals. The composition of the HF material flow of the windsifter contains $87 \mathrm{wt} \%$ of coarses (200-60 mm), where $45 \mathrm{wt} \%$ are pRDF and $37 \mathrm{wt} \%$ are inerts, in the form of stones. It is also important to highlight the amount of residuals, between $200-60 \mathrm{~mm}$, in the same material flow, which has a share of $13 \mathrm{wt} \%$.

Based on this information, particle size distributions of the LFM material and the results of this study can be used as guidance for mechanical treatment. Further chemical analyses are mandatory to determine whether the quality of the excavated material, e.g., fines and inerts, fits the standards for its recuperation.
See Appendix A-B for more results from each sampling point.

\subsection{Physical-chemical analysis}

Hull et al. pointed out in his study that waste fractions that can absorb moisture such as fines, paper, cardboard, wood and textiles had much higher moisture contents than fractions that cannot absorb water. However, it has to be considered that the size of the fines is another factor that influences the moisture content As can be observed from Table $6,<10 \mathrm{~mm}$ has a higher moisture content, $32 \mathrm{wt} \%$, than $10-20 \mathrm{~mm}$ and $20-40 \mathrm{~mm}, 17 \mathrm{wt} \%$ and $20 \%$, respectively, due to capillary forces on particles $<10 \mathrm{~mm}$.

Even if the results of this chapter are focused on the fines, moisture of samples containing all fractions could be almost equal. The mean moisture content of fines in previous investigations ranges from 16 to $43 \%$ (Hull et. al 2005).

The calorific value varies of the samples analysed from 7.2 to $11.9 \mathrm{MJ} / \mathrm{kg}$, depending on the share of organic content (<10 mm: 34.6 wt\%, 10-20 mm: 32.3 wt\%, 20-40 mm: $40.0 \mathrm{wt} \%)$.

The percentage of heavy metals contained in the fine fractions, reported in Table 7, are not below the Austrian limits, at least, to use the fine fraction for compost. In previous characterizations of landfilled material characterizations (Hull et al. 2005), selected trace metals also exceeded soil background levels and recommended levels when applying sewage biosolids to agricultural land.

There is an increase of the heavy metal content according to the diminution of the particle; $<10 \mathrm{~mm}$ has a higher concentration of heavy metals than $20-40 \mathrm{~mm}$. Further analysis is mandatory to estimate the potential of this fraction for construction material due to the amount of impurities (metals, glass shards and plastics).

\section{CONCLUSIONS}

The results from the investigations in Halbenrain landfill show that almost $90 \mathrm{t}$ of ferrous metals could be recovered from $2785 \mathrm{t}$ of mined landfill waste (approx. 3\%). However, even combined with the profit from nonferrous metals, the profit would be insufficient to make such a landfill mining project feasible today. This fact is further influenced negatively by the fact that the defilements on plastics that could e.g., be used for thermal valorization

TABLE 6: Mean values and standard deviation (in brackets) of the moisture content, organic content and calorific value of the input material in fine fractions (<10 mm; 10-20 mm: 20-40 mm).

\begin{tabular}{|c|c|c|c|c|c|c|c|c|c|c|c|}
\hline \multirow{2}{*}{$\begin{array}{l}\text { Input } \\
(\mathrm{mm})\end{array}$} & \multirow{2}{*}{$\begin{array}{c}\text { Moisture } \\
\text { (wt\% } \\
\text { semidry } \\
\text { basis) }\end{array}$} & \multicolumn{3}{|c|}{$\begin{array}{c}\text { Composition } \\
(w t \% d m)\end{array}$} & \multicolumn{3}{|c|}{$\begin{array}{l}\text { Organic content } \\
\qquad(w t \% d m)\end{array}$} & \multicolumn{4}{|c|}{$\begin{array}{l}\text { Calorific value } \\
(\mathrm{MJ} / \mathbf{k g ~ d m} *)\end{array}$} \\
\hline & & LF & HF & Metal & LF & HF & Metal** & LF & HF & Metal** & Total \\
\hline$<10$ & 32 & 7 & 91 & 2 & $\begin{array}{c}78.0 \\
(0.02)\end{array}$ & $\begin{array}{c}32.0 \\
(0.02)\end{array}$ & 0.0 & $\begin{array}{c}25.9 \\
(0.01)\end{array}$ & $\begin{array}{c}6.0 \\
(0.02)\end{array}$ & 0.0 & 7.2 \\
\hline $10-20$ & 17 & 18 & 77 & 5 & $\begin{array}{c}81.0 \\
(0.01)\end{array}$ & $\begin{array}{c}23.0 \\
(0.00)\end{array}$ & 0.0 & $\begin{array}{c}25.0 \\
(0.88)\end{array}$ & $\begin{array}{c}5.1 \\
(0.01)\end{array}$ & 0.0 & 8.5 \\
\hline $20-40$ & 20 & 23 & 73 & 4 & $\begin{array}{c}84.0 \\
(0.01)\end{array}$ & $\begin{array}{l}29.0 \\
(0.07)\end{array}$ & 0.0 & $\begin{array}{l}32.5 \\
(0.56)\end{array}$ & $\begin{array}{c}6.1 \\
(0.21)\end{array}$ & 0.0 & 11.9 \\
\hline
\end{tabular}

* dm: dry matter

** It is assumed the amount of organic content of the metals is $0 \mathrm{wt} \% \mathrm{dm}$; therefore, its calorific value is also $0 \mathrm{MJ} / \mathrm{kg} \mathrm{dm}$ 
TABLE 7: Mean and standard deviation (in brackets) of the heavy metals contained in the fine fractions: $<10 \mathrm{~mm}, 10-20 \mathrm{~mm}, 20-40$ $\mathrm{mm},(\%$, dry basis).

\begin{tabular}{|c|c|c|c|c|}
\hline \multirow{2}{*}{$\begin{array}{c}\text { Metals } \\
\%\end{array}$} & \multicolumn{3}{|c|}{ Fraction } & \multirow{2}{*}{$\begin{array}{c}\text { Limit values } \\
\text { * (\%) } \\
\text { [Austria, } \\
2018 \text { ] }\end{array}$} \\
\hline & $<10 \mathrm{~mm}$ & $10-20 \mathrm{~mm}$ & $20-40 \mathrm{~mm}$ & \\
\hline $\mathrm{Pb}$ & $\begin{array}{c}0.155 \\
(0.098)\end{array}$ & $\begin{array}{l}0.112 \\
(0.00)\end{array}$ & $\begin{array}{c}0.087 \\
(0.000)\end{array}$ & 0,020 \\
\hline As & $\begin{array}{c}0.007 \\
(0.000)\end{array}$ & $\begin{array}{l}0.007 \\
(0.00)\end{array}$ & $\begin{array}{c}0.002 \\
(0.000)\end{array}$ & - \\
\hline $\mathrm{Zn}$ & $\begin{array}{c}0.708 \\
(0.104)\end{array}$ & $\begin{array}{l}0.490 \\
(0.00)\end{array}$ & $\begin{array}{c}0.297 \\
(0.000)\end{array}$ & 0,180 \\
\hline $\mathrm{Ni}$ & $\begin{array}{c}0.046 \\
(0.002)\end{array}$ & $\begin{array}{l}0.025 \\
(0.00)\end{array}$ & $\begin{array}{c}0.026 \\
(0.000)\end{array}$ & 0,010 \\
\hline $\mathrm{Cr}$ & $\begin{array}{c}0.220 \\
(0.004)\end{array}$ & $\begin{array}{l}0.187 \\
(0.00)\end{array}$ & $\begin{array}{c}0.093 \\
(0.000)\end{array}$ & 0,025 \\
\hline $\mathrm{Cd}$ & $\begin{array}{c}0.003 \\
(0.000)\end{array}$ & $\begin{array}{l}0.003 \\
(0.00)\end{array}$ & $\begin{array}{c}0.004 \\
(0.000)\end{array}$ & $<0,001$ \\
\hline $\mathrm{Cu}$ & $\begin{array}{c}0.659 \\
(0.366)\end{array}$ & $\begin{array}{c}0.395 \\
(0.010)\end{array}$ & $\begin{array}{c}0.324 \\
(0.020)\end{array}$ & 0,050 \\
\hline
\end{tabular}

* General requirements for waste-compost, quality class $B$, in Austria (Bundesrecht konsolidiert: Gesamte Rechtsvorschrift für Kompostverordnung, Fassung vom 05.03.2018, BGBI. II Nr. 292/2001)

reduce the heating value and increase the ash content of such pRDF.

Furthermore, comparisons with previous landfill mining studies could be performed, even though such comparisons are made difficult by differences in landfill composition, preprocessing and the analytical approaches in such projects. However, certain similarities among this and former studies can be noted, such as similar amounts of fines (50 wt\%) and plastics (17 wt\%). In particular, the amounts of fines, $74 \mathrm{wt} \%<40 \mathrm{~mm}$ and $50 \mathrm{wt} \%<10 \mathrm{~mm}$, represent the biggest share of the excavated material, as Hernández Parrodi et al., 2017 also indicated in his study where this fraction can be as high as $40-80$ wt\% in various landfills around the world, and they need further investigation in order to reduce the financial burden they are today.

Moreover, fluctuations in the material compositions can be highly problematic. On one hand, these fluctuations can influence the load on different machines, potentially reducing the performance of the whole plant. On the other hand, such fluctuations, even if they might seem relatively small, can reduce the marketable fractions. Even if ferrous or non-ferrous products only make up a small amount of the total LFM material, when this amount varies between 1 and $5 \mathrm{wt} \%$, the amount of marketable product can also fluctuate approximately $500 \%$. Another problem with the mechanical process is the moisture of the material: if the material is not dry or semi-dried, as in this case for biological treatment, the quality of the sorting is lower, the amount of impurities adhered to the surface increases and the mass balance of each category would not be representative for the real composition (e.g., soil-type paper absorbs large amounts of water).

Chemical analysis reveals the presence of heavy metals in specific fractions. Depending on the further treatment of the different output fractions of such an LFM project, the limit values must be considered. Depending on the country
LFM material recovery should be conducted according to the applicable limit values, which can constitute a problematic hurdle and determine whether such a project can be viable.

Another inconvenience of landfill mining is the presence of hazardous materials, in addition to the contaminated soil, which drastically reduces the potential of the landfill as a source of resources. However, this inconvenience should not stop landfill mining activities, since the environmental issue that landfills entail cannot be ignored, and remediation strategies are necessary to avoid future costs.

\section{ACKNOWLEDGEMENTS}

This research has received funding from the European Union's Horizon 2020 Program ([H2020/2014-2019]) under Grant Agreement no. 721185 (MSCA-ETN NEW-MINE).

The authors would like to acknowledge the help from the Chair of Waste Processing Technology and Waste Management of Montanuniversität Leoben (Austria) and the support given by FCC Halbenrain Abfall Service Gesellschaft m.b.H. \& Co Nfg KG. This publication reflects only the author's view, exempting the Community from any liability. Project website: http://new-mine.eu/.

\section{REFERENCES}

Bhatnagar, A., Kaczala, F., Burlakovs, J., Kriipsalu, M., Hogland, M., \& Hogland, W. (2017). Hunting for valuables from landfills and assessing their market opportunities A case study with Kudjape landfill in Estonia. Waste management \& research : the journal of the International Solid Wastes and Public Cleansing Association, ISWA, 35(6), 627-635.

Brunner, P. H., \& Rechberger, H. (2015). Waste to energy--key element for sustainable waste management. Waste management (New York, N.Y.), 37, 3-12.

Bundesminister für Land- und Forstwirtschaft, Umwelt und Wasserwirtschaft verordne (2001). Verordnung des Bundesministers für Land- und Forstwirtschaft, Umwelt und Wasserwirtschaft über Qualitätsanforderungen an Komposte aus Abfällen (Kompostverordnung): BGBI. II Nr. 292/2001.

EURELCO (2017). NEW MINE - EU Training Network for Resource Recovery Through Enhanced Landfill Mining, from European Union's EU Framework Programme for Research and Innovation Horizon 2020: http://new-mine.eu/.

Eurostat (2014a). Classification of treatments: Directive 75/442/EEC.

Eurostat (2014b). Treatment of waste by waste category, hazardousness and waste operations, from http://appsso.eurostat.ec.europa.eu/nui/show.do?dataset=env_wastrt\&lang=en.

Ferranti, M. P. (op. 1985). Sorting of household waste and thermal treatment of waste. London: Elsevier.

G. A. Forster (1995). Assessment of Landfill Reclamation and the Effects of Age on the Combustion of Recovered Municipal Solid Waste.

Hernández Parrodi, J. C., Höllen, D., Pomberger, R. (2017). Characterization of fine fractions from landfill mining: A review of previous landfill mining investigations. Proceedings Sardinia 2017.

Hull, R. M., Krogmann, U., \& Strom, P. F. (2005). Composition and Characteristics of Excavated Materials from a New Jersey Landfill. Journal of Environmental Engineering, 131(3), 478-490.

Jani, Y., Kaczala, F., Marchand, C., Hogland, M., Kriipsalu, M., Hogland, W., \& Kihl, A. (2016). Characterisation of excavated fine fraction and waste composition from a Swedish landfill. Waste management \& research : the journal of the International Solid Wastes and Public Cleansing Association, ISWA, 34(12), 1292-1299.

Kaartinen, Tommi; Sormunen, Kai; Rintala, Jukka (2013): Case study on sampling, processing and characterization of landfilled municipal solid waste in the view of landfill mining. En: Journal of Cleaner Production 55, pág. 56-66. DOI: 10.1016/j.jclepro.2013.02.036. 
Kranert, M., \& Cord-Landwehr, K. (2010). Einführung in die Abfallwirtschaft (4., vollständig aktualisierte und erw. Aufl.). Vieweg Studium. Wiesbaden: Vieweg + Teubner.

Miller, Logan V., Mackey, Robert E., and Flynt, Jim (1991). "Excavation and Recyling Feasibility Study of a Municipal Solid Waste Landfill Utilizing Leachate Recycle. Report to Post Buckley, Schuh, and Jernigan, Inc and The Delaware Solid Waste Authority.

Ministerium für Umwelt und Forsten Rheinland-Pfalz (Dezember 1983): Grundregeln für die Entnahme von Proben aus Abfällen und abgelagerten Stoffen. Richtlinie für das Vorgehen bei physikalischen und chemischen Untersuchungen im Zusammenhang mit der Beseitigung von Abfällen. LAGA - RL. PN 2/78K.

Ministerium für Umwelt und Forsten Rheinland-Pfalz (Dezember 2001): Richtlinie für das Vorgehen bei physikalischen, chemischen und biologischen Untersuchungen im Zusammenhang mit der Verwertung/Beseitigung von Abfällen. LAGA PN 98.
Mönkäre, T. J., Palmroth, M. R. T., \& Rintala, J. A. (2016). Characterization of fine fraction mined from two Finnish landfills. Waste management (New York, N.Y.), 47(Pt A), 34-39.

Quaghebeur, M., Laenen, B., Geysen, D., Nielsen, P., Pontikes, Y., van Gerven, T., \& Spooren, J. (2013). Characterization of landfilled materials: Screening of the enhanced landfill mining potential. Journal of Cleaner Production, 55, 72-83.

Salerni, E.L. (1995). Landfill Reclamation Manual. Reclaim-95-Landfill Mining, 28-29, SWANA Landfill Reclamation Task Group.

Von Stein, E. L., Savage, G. M. (1993). Evaluation of the Collier Country, Florida, Landfill Mining Demostration. EPA/600/R-93/163.

Wolfsberger, T., Aldrian, A., Sarc, R., Hermann, R., Höllen, D., Budischowsky, A., et al. (2015). Landfill mining: Resource potential of Austrian landfills--Evaluation and quality assessment of recovered municipal solid waste by chemical analyses. Waste management \& research : the journal of the International Solid Wastes and Public Cleansing Association, ISWA, 33(11), 962-974.

\section{APPENDIX A: Tables}

TABLE i: Minimum number of individual/composite samples according to LAGA PN 98

\begin{tabular}{|c|c|c|c|c|c|c|c|}
\hline \multirow{2}{*}{$\begin{array}{c}\text { Name } \\
\text { sampling } \\
\text { point }\end{array}$} & \multirow{2}{*}{$\begin{array}{c}\text { Volume } \\
\mathrm{m}^{3}\end{array}$} & \multicolumn{3}{|c|}{ Theoretically } & \multicolumn{3}{|c|}{ Sampling campaign } \\
\hline & & $\begin{array}{l}\text { Individual samples } \\
\text { n }\end{array}$ & $\begin{array}{l}\text { Composite samples } \\
\mathbf{n}\end{array}$ & $\begin{array}{c}\text { Sample weight } \\
\text { Kg }\end{array}$ & $\begin{array}{l}\text { Individual samples } \\
\mathrm{n}\end{array}$ & $\begin{array}{l}\text { Composite samples } \\
\mathrm{n}\end{array}$ & $\begin{array}{c}\text { Sample weight } \\
\text { Kg }\end{array}$ \\
\hline SP1 & 400 & 32 & 8 & 15 & 18 * & 6 * & 21 \\
\hline SP2 & 30 & 8 & 2 & 15 & 8 & 2 & 12 * \\
\hline SP3 & 30 & 8 & 2 & 15 & 8 & 2 & 15 \\
\hline SP4 & 30 & 8 & 2 & 12 & 8 & 2 & 18 \\
\hline SP5 & 30 & 8 & 2 & 12 & 8 & 2 & 21 \\
\hline
\end{tabular}

* For technical reasons the number and the amount of the samples were not possible to reach in accordance to the guideline

TABLE ii: Composition by sampling point (\%wt semidry basis).

\begin{tabular}{|c|c|c|c|c|c|}
\hline Sampling point & Input <250 (SP1) & Fines SC 60 (SP2) & Coarses SC 200 (SP3) & Fines SC 200 (SP4) & HF WS (SP5) \\
\hline Fines $<10 \mathrm{~mm}$ & 49,3 & 70,6 & 7,2 & 9 & 1,3 \\
\hline Rest & 12,6 & 4,6 & 16,6 & 15,1 & 12,8 \\
\hline Plastic 2D & 10 & 2,8 & 28,9 & 15,5 & 1,2 \\
\hline Plastic 3D & 6,5 & 3,4 & 21,2 & 16 & 24,1 \\
\hline Inerts & 8,8 & 10,1 & 1,1 & 20,2 & 34,6 \\
\hline Wood & 5,2 & 2,7 & 8,1 & 13,2 & 19,6 \\
\hline Textile & 2,6 & 0,4 & 13,7 & 3,5 & 0,2 \\
\hline Paper & 1,3 & 1,2 & 0,9 & 3,2 & 0,9 \\
\hline Glass & 1,9 & 3,3 & 0,1 & 0,3 & 0,4 \\
\hline Fe metal & 1,4 & 0,7 & 1,8 & 2,9 & 3,2 \\
\hline NF metal & 0,4 & 0,2 & 0,4 & 1,1 & 1,7 \\
\hline
\end{tabular}

TABLE iii: Comparison of the composition by particle sizes in the fine fraction of the screen $60 \mathrm{~mm}$ (SP2), wt\%.

\begin{tabular}{|c|c|c|c|c|}
\hline Particle size (mm) & $<10$ & $10-20$ & $20-40$ & $40-60$ \\
\hline Fines $<10 \mathrm{~mm}$ & $100,0 \%$ & $0,0 \%$ & $0,0 \%$ & $0,0 \%$ \\
\hline RDF & $0,0 \%$ & $28,1 \%$ & $37,1 \%$ & $47,3 \%$ \\
\hline NF & $0,0 \%$ & $0,2 \%$ & $1,1 \%$ & $1,3 \%$ \\
\hline $\mathrm{Fe}$ & $0,0 \%$ & $2,2 \%$ & $1,9 \%$ & $3,6 \%$ \\
\hline Inerts & $0,0 \%$ & $37,6 \%$ & $32,9 \%$ & $30,5 \%$ \\
\hline Glass & $0,0 \%$ & $16,1 \%$ & $11,0 \%$ & $1,3 \%$ \\
\hline Residual & $0,0 \%$ & $15,8 \%$ & $15,9 \%$ & $16,1 \%$ \\
\hline
\end{tabular}


TABLE iv: High calorific materials by particle sizes in the fine fraction of the screen $60 \mathrm{~mm}$, wt $\%$.

\begin{tabular}{|c|c|c|c|c|}
\hline Particle size (mm) & $<10$ & $10-20$ & $20-40$ & $40-60$ \\
\hline Wood & $0,0 \%$ & $7,2 \%$ & $9,8 \%$ & $11,6 \%$ \\
\hline Paper & $0,0 \%$ & $4,5 \%$ & $3,4 \%$ & $3,8 \%$ \\
\hline Textile & $0,0 \%$ & $0,6 \%$ & $1,2 \%$ & $3,2 \%$ \\
\hline Plastic 2D & $0,0 \%$ & $6,5 \%$ & $9,9 \%$ & $14,6 \%$ \\
\hline Plastic 3D & $0,0 \%$ & $9,3 \%$ & $12,8 \%$ & $14,1 \%$ \\
\hline
\end{tabular}

TABLE v: Comparison of the composition by particle sizes in the output flow (>200mm) of the screen 200 , wt\%.

\begin{tabular}{|c|c|c|c|c|c|c|c|c|}
\hline Particle size (mm) & $<10$ & $10-20$ & $20-40$ & $40-60$ & $60-80$ & $80-100$ & $100-200$ & $200-250$ \\
\hline Fines $<10 \mathrm{~mm}$ & $100,0 \%$ & $0,0 \%$ & $0,0 \%$ & $0,0 \%$ & $0,0 \%$ & $0,0 \%$ & $0,0 \%$ & $0,0 \%$ \\
\hline RDF & $0,0 \%$ & $75,5 \%$ & $71,4 \%$ & $69,5 \%$ & $73,9 \%$ & $71,1 \%$ & $79,6 \%$ & $81,4 \%$ \\
\hline $\mathrm{NF}$ & $0,0 \%$ & $0,0 \%$ & $1,6 \%$ & $1,2 \%$ & $1,1 \%$ & $1,8 \%$ & $0,4 \%$ & $0,0 \%$ \\
\hline $\mathrm{Fe}$ & $0,0 \%$ & $0,0 \%$ & $1,5 \%$ & $0,6 \%$ & $0,9 \%$ & $0,1 \%$ & $1,4 \%$ & $3,4 \%$ \\
\hline Inerts & $0,0 \%$ & $2,7 \%$ & $3,1 \%$ & $11,8 \%$ & $0,6 \%$ & $4,7 \%$ & $0,0 \%$ & $0,0 \%$ \\
\hline Glass & $0,0 \%$ & $2,9 \%$ & $1,5 \%$ & $0,0 \%$ & $0,0 \%$ & $0,0 \%$ & $0,0 \%$ & $0,0 \%$ \\
\hline Residual & $0,0 \%$ & $18,9 \%$ & $21,0 \%$ & $17,0 \%$ & $23,5 \%$ & $22,2 \%$ & $18,6 \%$ & $15,2 \%$ \\
\hline
\end{tabular}

TABLE vi: High calorific materials by particle sizes in the output flow (>200mm) of the screen $200 \mathrm{~mm}$, wt\%.

\begin{tabular}{|c|c|c|c|c|c|c|c|c|}
\hline Particle size (mm) & $<10$ & $10-20$ & $20-40$ & $40-60$ & $60-80$ & $80-100$ & $100-200$ & $200-250$ \\
\hline Wood & $0,0 \%$ & $31,6 \%$ & $15,5 \%$ & $26,1 \%$ & $17,3 \%$ & $14,4 \%$ & $10,5 \%$ & $0,8 \%$ \\
\hline Paper & $0,0 \%$ & $9,1 \%$ & $8,1 \%$ & $3,7 \%$ & $2,1 \%$ & $1,2 \%$ & $0,5 \%$ & $0,0 \%$ \\
\hline Textile & $0,0 \%$ & $7,1 \%$ & $6,2 \%$ & $2,4 \%$ & $5,3 \%$ & $6,5 \%$ & $8,7 \%$ & $26,9 \%$ \\
\hline Plastic 2D & $0,0 \%$ & $16,8 \%$ & $16,4 \%$ & $18,5 \%$ & $23,5 \%$ & $23,4 \%$ & $35,5 \%$ & $32,9 \%$ \\
\hline Plastic 3D & $0,0 \%$ & $10,9 \%$ & $25,1 \%$ & $18,8 \%$ & $25,6 \%$ & $25,5 \%$ & $24,4 \%$ & $20,8 \%$ \\
\hline
\end{tabular}

TABLE vii: Comparison of the composition by particle sizes in the output flow $(<200 \mathrm{~mm})$ of the screen 200 , wt $\%$.

\begin{tabular}{|c|c|c|c|c|c|c|c|}
\hline Particle size (mm) & $<10$ & $10-20$ & $20-40$ & $40-60$ & $60-80$ & $80-100$ & $100-200$ \\
\hline Fines $<10 \mathrm{~mm}$ & $100,0 \%$ & $0,0 \%$ & $0,0 \%$ & $0,0 \%$ & $0,0 \%$ & $0,0 \%$ & $0,0 \%$ \\
\hline RDF & $0,0 \%$ & $54,5 \%$ & $64,2 \%$ & $63,2 \%$ & $39,2 \%$ & $48,5 \%$ & $64,5 \%$ \\
\hline NF & $0,0 \%$ & $1,9 \%$ & $0,1 \%$ & $1,7 \%$ & $1,9 \%$ & $0,2 \%$ & $1,5 \%$ \\
\hline $\mathrm{Fe}$ & $0,0 \%$ & $2,8 \%$ & $2,6 \%$ & $1,3 \%$ & $0,2 \%$ & $0,9 \%$ & $5,7 \%$ \\
\hline Inerts & $0,0 \%$ & $7,4 \%$ & $5,0 \%$ & $16,4 \%$ & $39,4 \%$ & $35,2 \%$ & $12,8 \%$ \\
\hline Glass & $0,0 \%$ & $3,5 \%$ & $1,4 \%$ & $1,6 \%$ & $0,3 \%$ & $0,0 \%$ & $0,0 \%$ \\
\hline Residual & $0,0 \%$ & $29,8 \%$ & $26,8 \%$ & $15,8 \%$ & $18,9 \%$ & $15,2 \%$ & $15,5 \%$ \\
\hline
\end{tabular}

TABLE viii: High calorific materials by particle sizes in the output flow $(<200 \mathrm{~mm})$ of the screen 200, wt\%.

\begin{tabular}{|c|c|c|c|c|c|c|c|}
\hline Particle size (mm) & $<10$ & $10-20$ & $20-40$ & $40-60$ & $60-80$ & $80-100$ & $100-200$ \\
\hline Wood & $0,0 \%$ & $11,7 \%$ & $24,5 \%$ & $25,2 \%$ & $10,5 \%$ & $15,4 \%$ & $12,9 \%$ \\
\hline Paper & $0,0 \%$ & $20,8 \%$ & $11,6 \%$ & $6,0 \%$ & $3,0 \%$ & $2,7 \%$ & $2,4 \%$ \\
\hline Textile & $0,0 \%$ & $1,7 \%$ & $1,3 \%$ & $1,4 \%$ & $2,0 \%$ & $1,3 \%$ & $6,4 \%$ \\
\hline Plastic 2D & $0,0 \%$ & $11,2 \%$ & $11,3 \%$ & $12,2 \%$ & $10,6 \%$ & $15,0 \%$ & $21,6 \%$ \\
\hline Plastic 3D & $0,0 \%$ & $9,2 \%$ & $15,5 \%$ & $18,4 \%$ & $13,1 \%$ & $14,1 \%$ & $21,2 \%$ \\
\hline
\end{tabular}


TABLE ix: Comparison of the composition by particle in the heavy fraction flow (HF) of the windsifter I, wt\%.

\begin{tabular}{|c|c|c|c|c|c|c|c|}
\hline Particle size (mm) & $<10$ & $10-20$ & $20-40$ & $40-60$ & $60-80$ & $80-100$ & $100-200$ \\
\hline Fines $<10 \mathrm{~mm}$ & $100,0 \%$ & $0,0 \%$ & $0,0 \%$ & $0,0 \%$ & $0,0 \%$ & $0,0 \%$ & $0,0 \%$ \\
\hline RDF & $0,0 \%$ & $35,1 \%$ & $45,6 \%$ & $58,5 \%$ & $38,4 \%$ & $41,7 \%$ & $55,2 \%$ \\
\hline NF & $0,0 \%$ & $3,1 \%$ & $0,0 \%$ & $0,9 \%$ & $1,8 \%$ & $0,9 \%$ & $2,8 \%$ \\
\hline $\mathrm{Fe}$ & $0,0 \%$ & $10,2 \%$ & $9,5 \%$ & $4,2 \%$ & $4,8 \%$ & $2,8 \%$ & $1,3 \%$ \\
\hline Inerts & $0,0 \%$ & $19,0 \%$ & $7,6 \%$ & $28,4 \%$ & $45,1 \%$ & $41,5 \%$ & $24,3 \%$ \\
\hline Glass & $0,0 \%$ & $4,7 \%$ & $2,8 \%$ & $1,4 \%$ & $0,6 \%$ & $0,0 \%$ & $0,0 \%$ \\
\hline Residual & $0,0 \%$ & $27,8 \%$ & $34,5 \%$ & $6,6 \%$ & $9,4 \%$ & $13,0 \%$ & $16,4 \%$ \\
\hline
\end{tabular}

TABLE x: Comparison of the composition by particle in the heavy fraction flow (HF) of the windsifter I, wt\%.

\begin{tabular}{|c|c|c|c|c|c|c|c|}
\hline Particle size (mm) & $<10$ & $10-20$ & $20-40$ & $40-60$ & $60-80$ & $80-100$ & $100-200$ \\
\hline Wood & $0,0 \%$ & $8,2 \%$ & $18,3 \%$ & $28,7 \%$ & $17,5 \%$ & $20,0 \%$ & $19,6 \%$ \\
\hline Paper & $0,0 \%$ & $5,2 \%$ & $4,3 \%$ & $0,7 \%$ & $0,5 \%$ & $1,0 \%$ & $0,7 \%$ \\
\hline Textile & $0,0 \%$ & $0,7 \%$ & $0,3 \%$ & $0,0 \%$ & $0,1 \%$ & $0,7 \%$ & $0,0 \%$ \\
\hline Plastic 2D & $0,0 \%$ & $4,6 \%$ & $2,2 \%$ & $1,5 \%$ & $0,4 \%$ & $1,7 \%$ & $1,1 \%$ \\
\hline Plastic 3D & $0,0 \%$ & $16,4 \%$ & $20,5 \%$ & $27,6 \%$ & $19,9 \%$ & $18,3 \%$ & $33,8 \%$ \\
\hline
\end{tabular}

\section{APPENDIX B: Figures}

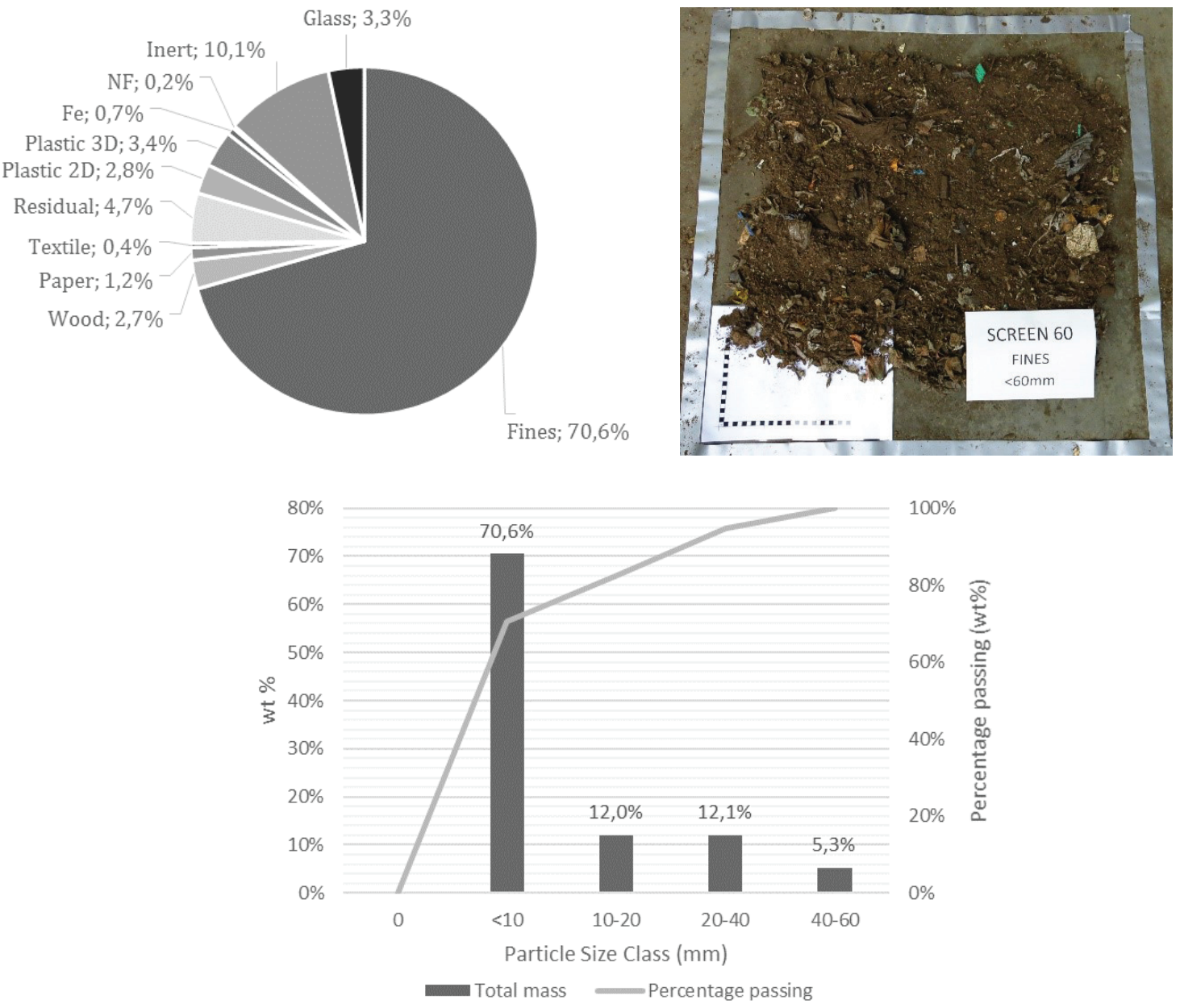

FIGURE i: Average composition of the fine fraction of the screen $60 \mathrm{~mm}, \mathrm{SP} 2$, (up) and its particle size distribution (down). 

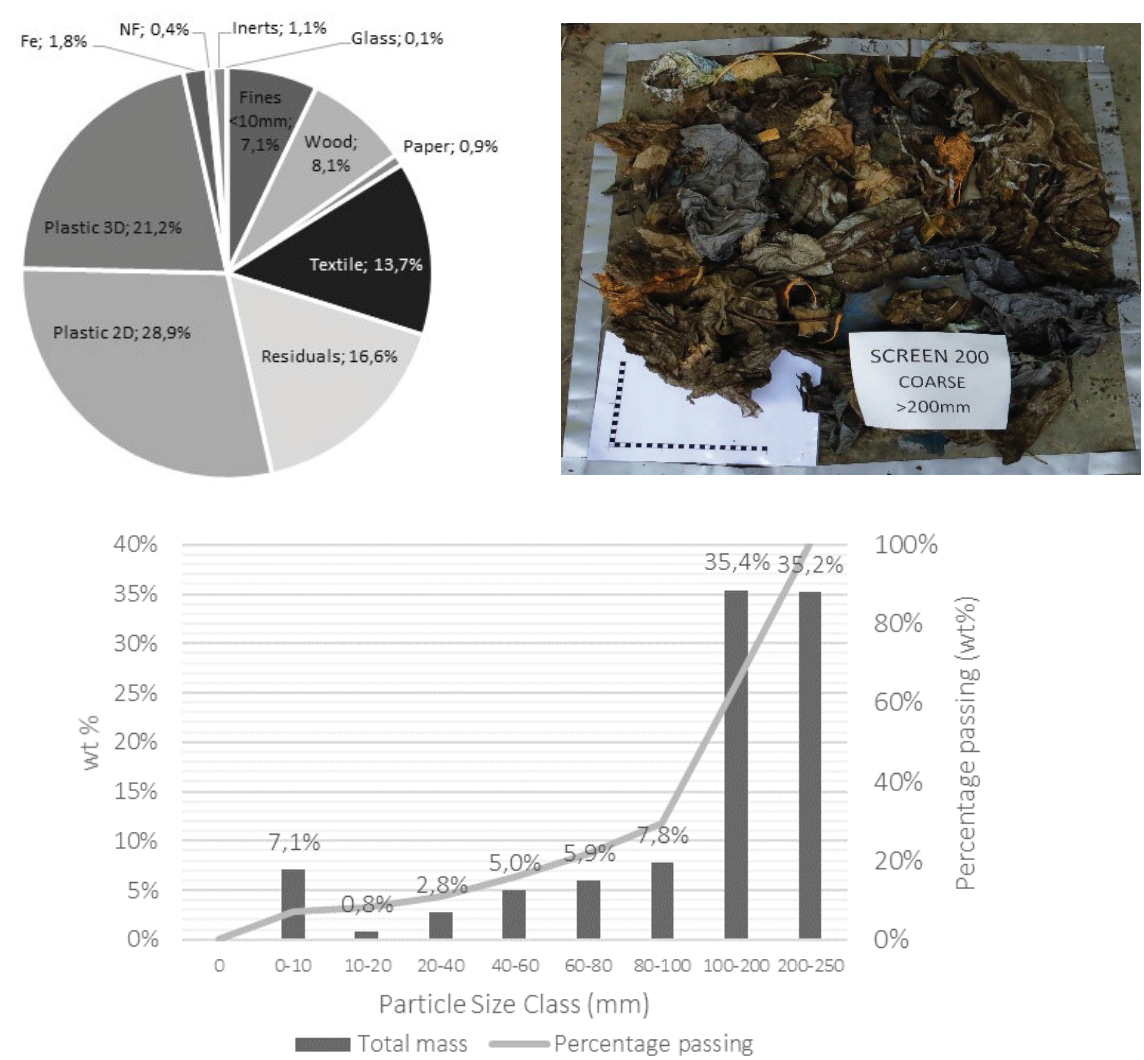

FIGURE ii: Average composition of the coarse fraction (250-200 mm) of the screen 200, SP3, (up) and its particle size distribution (down).
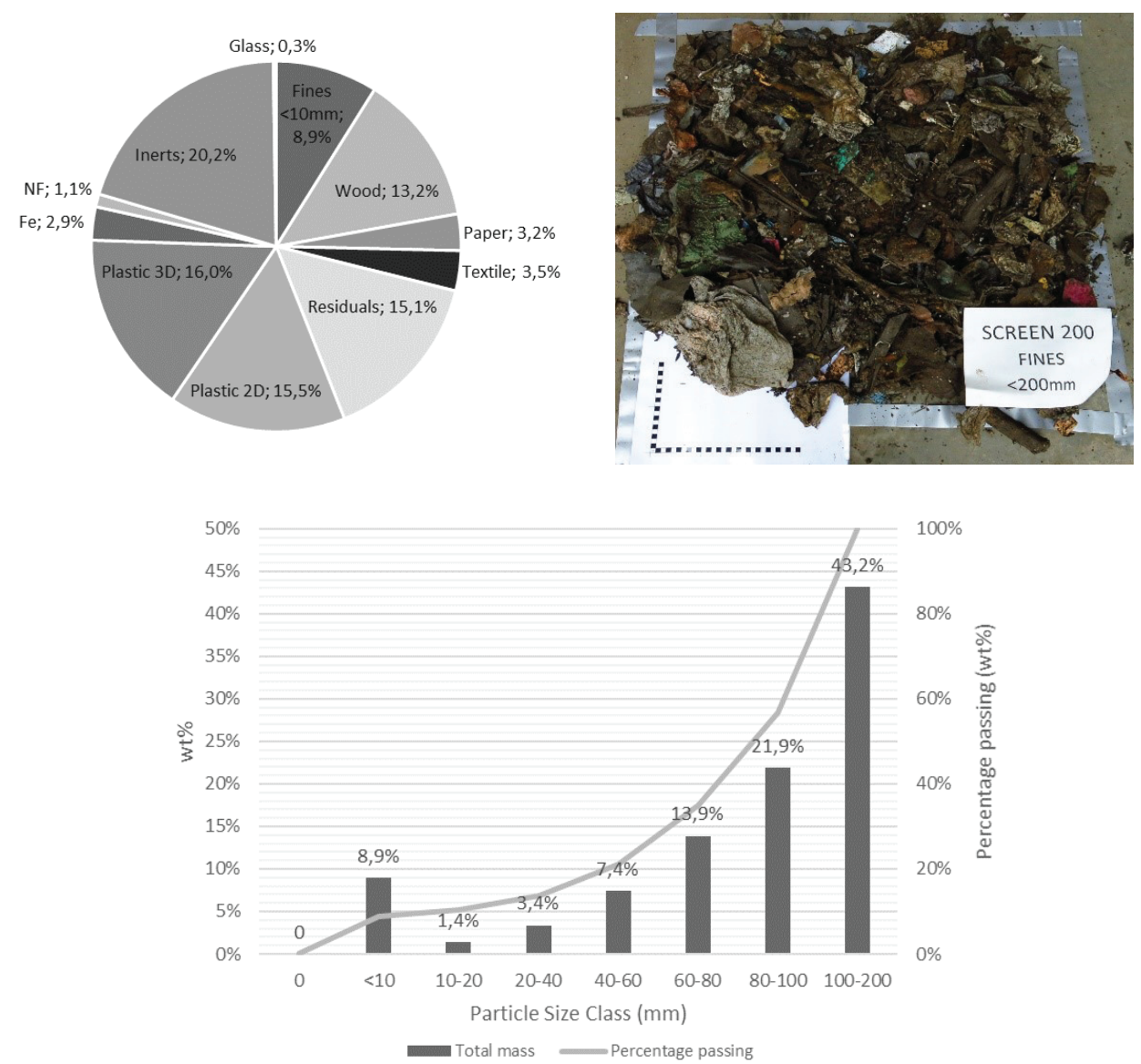

FIGURE iii: Average composition of the fine fraction (<200 mm) of the screen 200, SP4, (up) and its particle size distribution (down). 

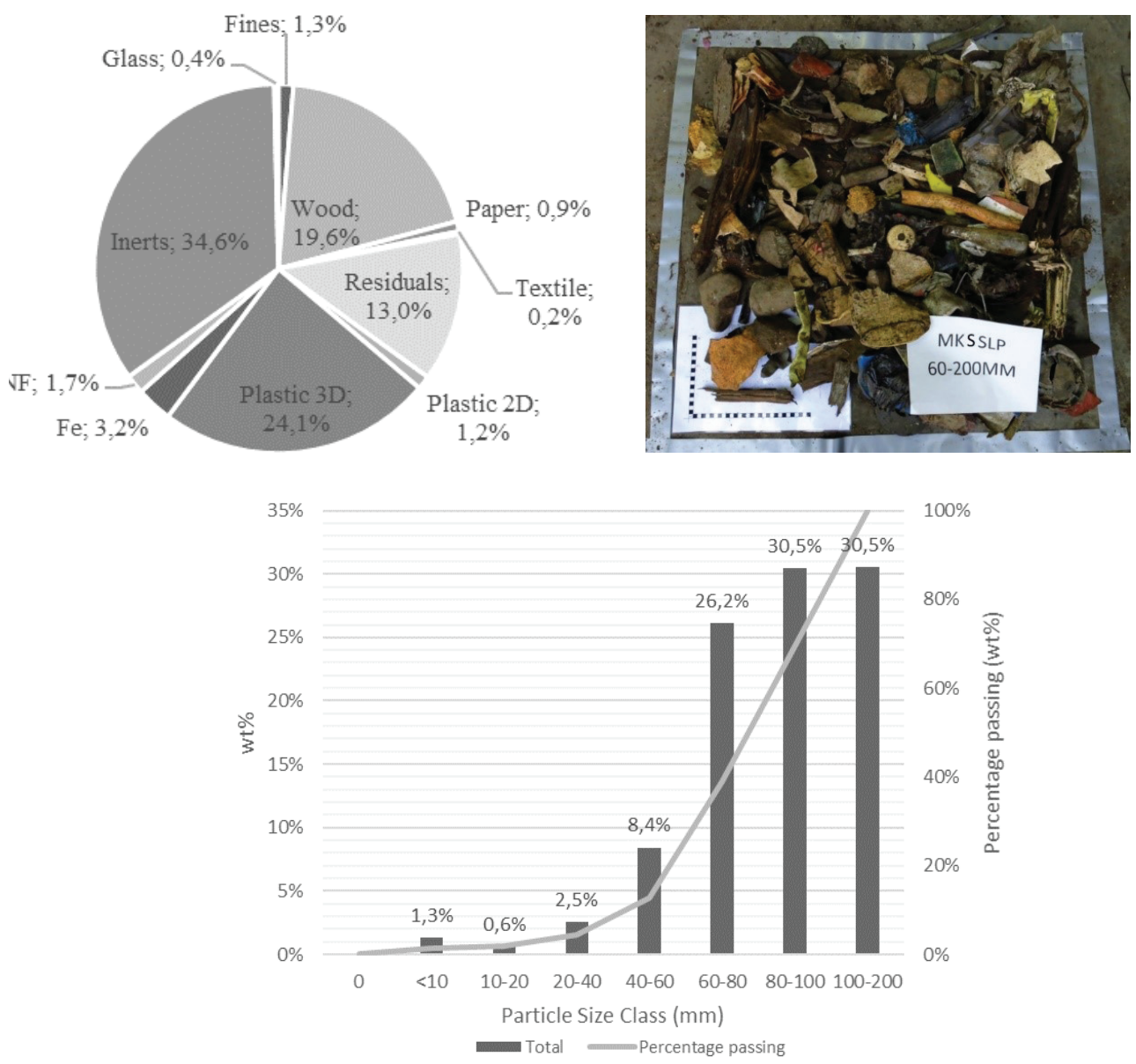

FIGURE iv: Average composition of the heavy fraction (HF) windsifter, SP5, (up) and particle size distribution (down). 